\title{
Türk Kamu Yönetiminde Ticaret Odaları ve Ticaret Borsaları Personeli Sorunu Araştırmasıı ${ }^{1}$
}

\author{
Personnel Problems in The Chambers of Commerce And Commodity Exchanges in Turklsh Public \\ Administration
}

Süleyman Ruhi AYDEMIR

Dr., Ticaret Bakanlı̆̆l Başmüfettişi,

sraydemir@yahoo.com

https://orcid.org/0000-0001-8443-8234
Makale Başvuru Tarihi: 14.03.2020

Makale Kabul Tarihi: 07.05.2020

Makale Türü: Araştırma Makalesi

Anahtar
Kelimeler:
Oda,
Borsa,
Personel,
Kurumsallaşma,
Istihdam,

Chamber of

Commerce,

Commodity

Exchange,

Personnel,

Institutionalization,

Employment,

\section{ÖZET}

Bu çalışmanın amact, iki farklı personel rejimiyle ticaret odaları ve ticaret borsalarında istihdam edilen personelin; genel statü, istihdam edilme, yükselme, hukuki korunma, emeklilik, sicil işlemleri, mali özlük hakları ve görev tanımlarına dair uygulamaları karşılaşıtırmak, ulaşılan sonuçlar ve yapılan tespitleri ortaya koyarak bu alana katkıda bulunabilmek, ticaret odalarl ve ticaret borsalarında istihdam edilen personelin sorunların ortaya koyabilmek ve bu sorunları demografik özelliklerine göre farklılaşma durumunu incelemektir. Bu doğrultuda yapılan araştırmada, personelin kurumsallaşma ve iç işleyişe, istihdama ve özlük haklarına yönelik sorunlara yaklaşım düzeylerinin, cinsiyet, eğitim düzeyi, çalışılan kurum türü, kurumun bulunduğu bölge, kurumun yerleşim yeri, çalışma yılı, (statü) işe giriş tarihi, aylık ortalama maaş aralığ $\breve{l}$ ve pozisyonlara göre farklılaşıp farklılaşmadığının cevabı aranmıştır. Anketlerden elde edilen veriler bilgisayar ortamında SPSS 23.0 istatistik paket programı aracılı̆̆ıyla çözümlenmiştir. Araştırmaya katılanların tanımlayıcı özelliklerinin belirlenmesinde frekans ve yüzde istatistiklerinden, bulguların çapraz test ve Khi-kare değerlendirilmesinde bağımsız değişkenlerden cinsiyet, eğitim düzeyi, çalışılan kurum türü, kurumun bulunduğu bölge, kurumun yerleşim yeri, (statü) işe giriş tarihi, aylık ortalama maaş aralığı ve pozisyon ele alınmıştır. Araştırma sonucunda ortaya çıkan bulgular, farklı personel rejimlerine tabi personelin aynı kurumda bir arada çalışmasının sorunlara yol açtı̆̆l, yönetim değişimlerinden personelin yoğun olarak etkilendiği, genel kabul görmüş insan kaynaklarl yönetimindeki temel ilkelere riayet edilmediği ve kamu kurumu niteliğindeki bu meslek kuruluşlarında kurumsallaşmanın çok düşük düzeyde olduğu yönündedir.

\section{ABSTRACT}

The aim of this study is to compare the practices of general status, employment, promotion, legal protection, retirement, registration procedures, financial personal rights and job descriptions of personnel employed by two different personnel regimes in the chambers of commerce and commodity exchanges, to be able to contribute to this field by revealing the determinations, to reveal the problems of the personnel employed in the chamber of commerces and commodity exchanges, and to examine the differentiation according to the demographic characteristics of these problems. The main purpose of this research is to determine the level of attitudes of the personnel participating in the research to the issues related to institutionalization and internal affairs, employment and personal rights, gender, education level, institution type, place of institution, settlement place, date of employment, monthly average salary range and positions. The data obtained from the questionnaires were analyzed by SPSS 23.0 statistical package program on the computer environment. Frequency and percentage statistics were used to determine the descriptive characteristics of the participants in the study. In the cross-test and chi-square analysis of the findings, gender, education level, type of institution studied, institutional location, institutional residence, date of employment, monthly average salary range and position is discussed. According to the results of the research, it is found that the staff members of different personnel regimes cause problems in the same institution, the personnel are influenced by the management changes, the basic principles of the generally accepted human resources management are not respected and institutionalization in these professional institutions as public institutions is very low.

1 Bu çalışma yazarın, Doç. Dr. Yakup ALTAN danışmanlığında hazırlanan ve 09 Mayıs 2018 tarihinde Isparta Süleyman Demirel Üniversitesi Sosyal Bilimler Enstitüsü Kamu Yönetimi Ana Bilim Dalında savunulmuş ve oybirliği ile kabul edilmiş olan "Türk Kamu Yönetiminde Ticaret Odaları ve Ticaret Borsaları Personel Sorunu" başlıklı doktora tezinden (Ulusal Tez Merkezi Tez No: 498215) üretilmiştir. 


\section{GIRISS}

İki farklı personel rejimiyle istihdam edilen odalar ve borsalar personelinin genel statü, istihdam edilme, yükselme, hukuki korunma, emeklilik, sicil işlemleri, mali özlük hakları ve görev tanımlarına dair uygulamaları karşılaştırmak, ulaşılan sonuçlar ve yapılan tespitlerin ortaya konması ile bu alana katkıda bulunabilmek, bu personelin sorunlarını ortaya koyabilmek ve bu sorunların demografik özelliklerine göre farklılaşma durumunu incelemek amacıyla hazırlanan bu çalışmada saha araştırmasının sonuçları yer almaktadır.

Saha araştırmasında nicel araştırma tekniği kullanılmıştır. Elde edilen veriler çapraz test ve Khi-kare testleri test edilerek sonuçları ortaya konmuştur. Yapılan araştırma sonucunda; iş güvencesinin yok olduğu, Yönetim kurullarının kurumu kendi işyerleri gibi yönettiği, fırsat ve imkânların adil ve şeffaf olarak tüm çalışanlara sunulmadığı, personelin başarılarının takdir edilemediği, kararların demokratik şekilde alınmamadığı, kurum içinde yetki ve sorumluluklar dengeli şekilde dağıtılmadığı, yönetim kurulu yakını olmanın istihdamın ana şartı haline dönüştiği, kurumda yapılan atama ve terfilerde liyakate dikkat edilmediği, yazılı ve sözlü cezalandırmalarda personel arasında ayrım yapıldığı, çalışanların yarıdan fazlasının geçim sıkıntısı çektiği, çalışanlar arasındaki maaş aralıklarının adil olmayan bir şekilde olduğu, maaşların yetki, görev ve sorumluluk dikkate alınarak belirlenmediği, çalışanların haklarını yeterince kullanamadıkları sonucuna ulaşılmıştır. Çalışmada "Ticaret Odası" kavramıla; 'Ticaret Odası', 'Ticaret ve Sanayi Odası', 'Sanayi Odası' ve 'Deniz Ticaret Odası' kavramlarının tamamına işaret edilmektedir.

\section{ODALAR VE BORSALARIN TEMEL ÖZELLİKLERİ İLE PERSONELINIIN HUKUKİ DURUMU}

Dünyadaki sosyo ekonomik, bilimsel ve teknolojik gelişmeler neticesinde devletin zamanla kamusal yükü artmıştır. Bunun karşısında devlet, bir taraftan kamu yararı ile yakın ilgisi bulunan meslekleri düzenlerken, bir taraftan da bu mesleklerden belirli bir olgunluğa erişmiş olanları özerk hale getirerek, kendisine ait bazı yetkileri bunlara devretmektedir (Özer, 1994:38). Böylece, bu teşkilatlar kamusal kuruluşlar haline gelmişlerdir.

Kamu kurumu niteliğindeki meslek kuruluşları, önceleri serbest meslek olarak adlandırılan mesleklerde üyelerinin çıkarlarını korumak için dernek veya cemiyet niteliğinde meslek kuruluşları şeklinde kurulmuş iken, zamanla kamusal kuruluşlar haline gelmişler ve sayıları da giderek artmıştır. Bu kuruluşlar, devletin bazı meslekleri kamu yararı ile fazla ilgili görmesi neticesinde, bu meslek mensuplarının faaliyetlerini düzenlemesi ve denetlemesi ihtiyacından doğmuştur (Versan, 1986:260).

1982 Anayasasının 135'nci maddesine göre kamu kurumu niteliğindeki meslek kuruluşlarının amacı; "Belli bir mesleğe mensup olanların müşterek ihtiyaçlarını karşılamak, mesleki faaliyetlerini kolaylaştırmak, mesleğin genel menfaatlere uygun olarak gelişmesini sağlamak, meslek mensuplarının birbirleri ile ve halk ile olan iliş̧kilerinde dürüstlü̈̆̈̈ ve güveni hâkim kılmak üzere meslek disiplinini ve ahlakını korumak"tır.

Odalar ve borsalar kamu tüzel kişiliğine sahiptirler. Bu bağlamda özel hukuk tüzel kişiliklerinden ayrılırlar. Kamu hukuku tüzel kişileri ile özel hukuk tüzel kişileri arasındaki farklar şu şekilde sıralanmıştır (Parlak ve Sobac1, 2012:32; Y1ldırım, 2005:19);

- Gerçek kişilerin serbest iradelerine dayanan özel hukuk tüzel kişilerinin kuruluşu için kanuni dayanağa ihtiyaç yoktur. Kamu tüzel kişileri ise devlet tarafindan kanunla veya kanunun verdiği açık yetkiye dayanılarak idari işlemle kurulurlar.

- Kamu tüzel kişileri kamu gücü ayrıcalıklarından yararlanır ve bu nedenle özel hukuk tüzel kişilerinden üstün konumdadırlar.

- Özel hukuk tüzel kişilerinin faaliyet amacı birtakım özel yararların gerçekleştirilmesidir. Kamu tüzel kişilerinin amacı ise kamu yararını gerçekleştirmektir.

Bir tüzel kişinin "Kamu Tüzel Kişisi” olmasının 2 şartı vardır. Bunlardan ilki, tüzel kişinin Devlet tarafından kurulmuş olmasıdır. Anayasanın 123'üncü maddesi çerçevesinde bir tüzel kişinin ya kanunla kurulmuş olması ya da kanun tarafından verilen açık bir yetkiye dayanılarak idarece kurulmuş olması gerekmektedir (Parlak ve Sobac1, 2012:33, Gözübüyük, 2010:92). İkinci şart ise, Devlet tarafından kurulan tüzel kişinin, kamu gücü ayrıcalıklarına sahip olmasıdır (Parlak ve Sobacı, 2012:33). Bir tüzel kişiliğin kamu gücü ile donatılması ile bu tüzel kişilik (Gözübüyük ve Tan, 2011:155-160, Günday, 2011:77-80, Gözler, 2003:143-165); 
- Tek yanlı işlemler yapabilme ve resen icra yetkisine sahiptirler. Hak ve fiil ehliyetine sahip oldukları için hak ve borç altına girebilirler, hukuki işlemler yapabilirler, gerek özel kişilere, gerek diğer kamu tüzel kişilerine karşı mahkemelerde dava açabilirler.

- İşlemlerini yerine getirirken "hukuka uygunluk karinesi”nden yararlanırlar.

- Kendilerine ait mal varlığına sahiptirler ve malları kamu malı statüsüne tâbi tutulur.

- Gelirleri kamu gelirleri statüsünde sayılır ve tahsilinde 6183 sayılı Amme Alacaklarının Tahsili Usulü Hakkında Kanun ${ }^{2}$ uygulanır.

- Malları hakkında cebrî icra hükümleri uygulanamaz, mallarının haczedilemez ve iflasları istenemez.

- İdari ve mali özerkliğe sahip olup, kendilerine ait bütçeleri ve personeli vardır. Türk ceza kanununun uygulaması bakımından personel, devlet memuru olarak kabul edilir.

- Üye olmak zorunludur ve bundan dolayı aidat ödenir.

- Kendi iradelerini yansıtacak organlara sahiptirler. "yönetmelik" çıkarma gibi düzenleme yetkilerine sahiptirler,

5174 sayılı Kanuna göre Odalar; üyelerinin müşterek ihtiyaçlarını karşılamak, meslekî faaliyetlerini kolaylaştırmak, mesleğin genel menfaatlere uygun olarak gelişmesini sağlamak, mensuplarının birbirleri ve halk ile olan ilişkilerinde dürüstlüğü ve güveni hâkim kılmak üzere meslekî disiplin, ahlâk ve dayanışmayı korumak ve bu Kanunda yazılı hizmetler ile mevzuatla odalara verilen görevleri yerine getirmek amaciyla kurulan tüzel kişiliğe sahip kamu kurumu niteliğinde meslek kuruluşlarıdır.

Odaların, meslek ahlâkını, disiplini ve dayanışmanın korunması ve geliştirilmesi, ticaret ve sanayinin kamu yararına uygun olarak gelişmesine çalışılması, ticaret ve sanayiyi ilgilendiren bilgi ve haberleri derleyerek ilgililere ulaştırılması, üyelerinin mesleklerini yerine getirmede ihtiyaç duyabilecekleri her çeşit bilgiyi, başvuruları durumunda kendilerine verilmesi veya bunların elde edilmesini kolaylaştırılması, elektronik ticaret ve internet ağları konusunda üyelerine yol gösterecek girişimlerde bulunulması, bu konularda gerekli alt yapıyı kurulması ve işletilmesi, ticaret ve sanayiye ait her türlü incelemeleri yapmak, bölgeleri içindeki iktisadî, ticarî ve sınaî faaliyetlere ait endeks ve istatistiklerin tutulması, başlıca maddelerin piyasa fiyatlarını takip ve kaydedilmesi ve bunların ilan edilmesi, fuarlara katılınması, kanunda sayılan belgeleri düzenlenmesi ve onaylanması, meslek faaliyetlerine ait konularda resmî makamlara teklif, dilek ve başvurularda bulunulması, mesleki menfaati olduğu takdirde dava açılması, ticarî ve sınaî örf, adet ve teamüllerin tespit edilmesi, üyeleri tarafından uyulması zorunlu meslekî karar alınması görev ve yetkileri bulunmaktadır.

Ticaret borsaları ise borsaya dahil maddelerin alım satımı ve borsada oluşan fiyatlarının tespit, tescil ve ilânı işleriyle meşgul olmak üzere kurulan kamu tüzel kişiliğine sahip kurumlardır ve borsaya dahil maddelerin, borsada alım satımını tanzim ve tescil etme, borsaya dahil maddelerin borsada oluşan her günkü fiyatlarını usulü dairesinde tespit ve ilân etmek, alıcı ve satıcının, teslim ve teslim alma ile ödeme bakımından yükümlülüklerini, muamelelerin tasfiye şartlarını, fiyatlar üzerinde etkili şartları ve ihtilaf doğduğunda ihtiyari tahkim usullerini gösteren ve birliğin onayıyla yürürlüğe girecek genel düzenlemeler yapmak, yurt içi ve yurt dışı borsa ve piyasaları takip ederek fiyat haberleşmesi yapmak, elektronik ticaret ve internet ağları konusunda üyelerine yol göstermek, sayılan belgeleri düzenlemek ve onaylamak, borsaya dahil maddelerin tiplerini ve vasıflarını tespit etmek üzere lâboratuvar ve teknik bürolar kurmak veya kurulmuşlara iştirak etmek, bölgeleri içindeki borsaya ilişkin örf, adet ve teamülleri tespit ve ilân etmek, borsa faaliyetlerine ait konularda ilgili resmî makamlara teklif, dilek ve başvurularda bulunmak, üyelerinin tamamı veya bir kesiminin menfaati olduğu takdirde bu üyeleri adına veya kendi adına dava açmak, rekabeti bozucu etkileri olabilecek anlaşma, karar ve uyumlu eylem niteliğindeki uygulamaları izlemek ve tespiti halinde ilgili makamlara bildirmek görevleri bulunmaktadır.

Kamu kurumu nitelikleri, 18.05.2004 tarihli ve 5174 sayılı Türkiye Odalar ve Borsalar Birliği ile Odalar ve Borsalar Kanunu'nun ${ }^{3} 4$ ve 28 'nci maddeleriyle yasal hükme kavuşturulan ticaret odaları ve ticaret borsalarının personeline uygulanan hükümler mülga 1950 tarihli 5590 sayılı Kanuna ${ }^{4}$ dayanılarak çıkartılan 1983 tarihli Personel Yönetmeliği ${ }^{5}$ ile 1994 tarihli Personel Sicil Yönetmeliği ${ }^{6}$ 'ne dayanmaktadır.

2 28.07.1953 tarihli ve 8469 sayılı Resmi Gazete.

3 01.06.2004 Tarihli ve 25479 sayılı Resmi Gazete.

15.03.1950 Tarihli ve 7457 sayılı Resmi Gazete.

5 Bu yönetmelik, Bakanlar Kurulu'nun 18.5.1983 tarih ve 83/6620 sayılı Kararı ile kabul edilerek 05.08.1983 gün ve 18126 sayılı Resmi Gazete'de yayımlanmış ve 01.09.1983 günü yürürlüğe girmiştir. 
Tarihsel süreç içerisinde; 1925 tarihli 655 sayılı Ticaret ve Sanayi Odaları Kanununda; odalar ve borsalarda istihdam edilen personel ile ilgili hiçbir düzenleme bulunmamaktadır. 1943 yılına kadar devam eden bu süreç 4355 sayılı Kanunla kırılmıştır. 1943 yılında çıkarılan 4355 sayılı Ticaret ve Sanayi Odaları, Esnaf Odaları ve Ticaret Borsaları Kanunu ve bu Kanun'un uygulanması ile ilgili olarak konulan 2/19900 sayıl1 Ticaret ve Sanayi Odaları, Esnaf Odaları ve Ticaret Borsaları Nizamnamesi ${ }^{8}$, odalar ve borsalar için bazı ortak düzenlemeler getirmiştir.1943 tarihli 2/19900 sayılı Tüzükte memurlar ve hizmetliler olarak ilk defa hizmet sınıfları dile getirilmiştir. Memurlar, hizmetliler ve yevmiyeli memurlar şeklinde hizmet sınıflandırılmasının yer aldığı 1951 tarihli 3/13070 sayılı Tüzükte memurlar daimi ve geçici olarak 2 farklı bir düzenlemeye tabi tutulmuştur

Ticaret ve sanayi odaları ile ticaret borsalarının yeniden düzenlenmesi ihtiyacından dolayı hazırlanan 08.03.1950 tarihli 5590 say1l Kanun; odalar ve borsalarda istihdam edilen memur ve hizmetlilerle ilgili tayin, terfi, çıkarma ve diğer özlük haklarına ilişkin hususların tüzükle düzenleneceğini ifade etmiş ve bu doğrultuda 3/13070 sayılı olarak anılan Tüzük 1951 tarihinde yürürlüğe girmiştir. Bu dönemde, odalar ve borsalarda istihdam edilen personelle ilgili yapılan düzenlemelerden ikincisi olan ve 3/13070 sayılı tüzüğü değiştiren 1978 tarihli 7/15178 sayılı tüzük ise 1965 tarihli 657 sayılı Devlet Memurları Kanununu esas alarak hazırlanmış ve 18.05.1983 tarihli Bakanlar Kurulu Kararıla 05.08.1983 tarihli Resmi Gazetede yayımlanan "Türkiye Ticaret Odaları ve Borsaları Birliği Personel Yönetmeliği"ne (Personel Yönetmeliği) kadar yürürlükte kalmıştır.

5590 sayılı Kanun bağlamında düzenlenmiş bulunan 1983 tarihli Personel Yönetmeliğinde ele alınan hizmet sınıflandırmalarının temeli 1978 tarihli 7/15178 sayılı Tüzükte atılmıştır. Bu Tüzükte dile getirilen işçi kavramı personel yönetmeliğinde olmamasına rağmen 2004 tarihli 5174 sayılı Kanunla tam anlamıyla işçi istihdamına geçilmiş̧ir. Hizmet sınıfları itibarıyla oda ve borsa personelinin statüsel bağlamda evrimi aşağıdaki gibidir.

Tablo 1. Tarihsel Süreç İçerisinde Personelin Evrimi

\begin{tabular}{|c|c|c|}
\hline Kanun & Tüzük & Hizmet Sinıfları \\
\hline $\begin{array}{c}22 \text { Nisan } 1925 \text { tarihli } 655 \text { sayılı Ticaret ve } \\
\text { Sanayi Odaları Kanunu }\end{array}$ & - & - \\
\hline $\begin{array}{c}\text { 11.01.1943 tarihli } 4355 \text { sayılı Ticaret ve } \\
\text { Sanayi Odaları, Esnaf Odaları ve Ticaret } \\
\text { Borsaları Kanunu }\end{array}$ & $\begin{array}{l}\text { 21.05.1943 tarihli } 2 / 19900 \\
\text { say1lı Tüzük }\end{array}$ & $\begin{array}{l}\text { Memurlar } \\
\text { Hizmetliler }\end{array}$ \\
\hline \multirow{3}{*}{$\begin{array}{l}\text { 08.03.1950 tarihli } 5590 \text { sayılı Ticaret ve } \\
\text { Sanayi Odaları", "Ticaret Odaları", } \\
\text { "Sanayi Odaları", "Deniz Ticaret Odaları", } \\
\text { "Ticaret Borsaları" ve "Türkiye Ticaret, } \\
\text { Sanayi, Deniz Ticaret Odaları ve Ticaret } \\
\text { Borsaları Birliği" Kanunu }\end{array}$} & $\begin{array}{l}\text { 21.05.1951 tarihli } 3 / 13070 \\
\text { say1lı Tüzük }\end{array}$ & $\begin{array}{l}\text { Memurlar } \\
\text { Daimi Memurlar } \\
\text { Geçici Memurlar } \\
\text { Hizmetliler } \\
\text { Yevmiyeli Memurlar }\end{array}$ \\
\hline & $\begin{array}{l}\text { 10.05.1978 tarihli } 7 / 15178 \\
\text { say1lı Tüzük }\end{array}$ & $\begin{array}{l}\text { Memurlar } \\
\text { Sözleşmeli personel, } \\
\text { Geçici personel } \\
\text { İşçiler }\end{array}$ \\
\hline & \multirow{2}{*}{$\begin{array}{c}\text { 05/08/1983 tarihli Personel } \\
\text { Yönetmeliği }\end{array}$} & $\begin{array}{c}\text { Memurlar } \\
\text { Hizmetliler } \\
\text { Sözleşmeli Personel } \\
\text { Geçici Personel }\end{array}$ \\
\hline $\begin{array}{c}\text { 01.06.2004 Tarihli } 5174 \text { sayılı Türkiye } \\
\text { Odalar ve Borsalar Birliği ile Odalar ve } \\
\text { Borsalar Kanunu }\end{array}$ & & İşçiler \\
\hline
\end{tabular}

1983 tarihli Personel Yönetmeliği; odalar ve borsalar personelini; memurlar, sözleşmeli ve geçici personel olarak sınıflandırmış, bunların ödev ve sorumlulukları ile onlar için konulan yasaklar 657 sayılı Devlet Memurları Kanunu ile ilişkilendirilmiştir. 5174 sayı1ı Kanunu'nun 73'ncü maddesiyle "oda, borsa, birlik ve bunların kurduğu teşekküllerde istihdam edilenler bu kanunda yer alan hükümler dışında 4857 sayılı İş Kanununa tâbidir" hükmü getirilmiş, böylelikle odalar ve borsalarda çalışan personelin istihdam rejiminde radikal bir değişiklik yapılarak istihdamda esnekleşmeye gidilmiştir.

Kanun'da bulunan geçici 12'nci maddede ile; kanunun yürürlüğe girdiği tarihte (01.06.2004) oda, borsa, birlik ve bunların kurduğu teşekküllerde istihdam edilmekte olanların, mevcut statülerine göre istihdam edilecekleri belirtilmiştir. Böylelikle odalar ve borsalarda 5590 sayılı kanuna dayanılarak çıkartılan personel yönetmeliğine 
tabi statü hukuku uygulanan personel ile 5174 sayılı kanunun yayımından sonra istihdam edilen iş hukukuna tabi esnek hukuk uygulanan iki farklı personel rejimi ortaya çıkmış, asli ve sürekli görevlerde çalışan personelin sözleşmeli çalıştırılmasının önü açılmıştır. Bunun dışında; Personel Yönetmeliği'nde yer alan genel sektererlerin istihdamında bu kuruluşlardaki en üst karar organı Meclisin onayı kaldırılmıştır.

Odalar ve borsalarda istihdam edilen personelin hukuki durumlarını açıklayıcı bir düzenleme bulunmamaktadır. 657 sayılı Devlet Memurları Kanunu açısından memur sayılıp sayılmadıkları ile anayasada belirtilen diğer kamu görevlileri kavramı içinde olup olmayacağı tartışılırken bazı mevzuat hükümleri karşısında Türk Ceza Kanunu açısından memur sayılmaktadırlar. Bu personel idari yargı kararlarından memurluk kavramının sağladığı güvenceye sahip oldukları ortaya çıkmaktadır.

\section{ARAŞTIRMANIN AMACI VE ÖNEMI}

2020 yılı itibarıla ülkemizde 57 Ticaret Odası, 181 Ticaret ve Sanayi Odası, 113 Ticaret Borsası, 12 Sanayi Odası ve 2 Deniz Ticaret Odası olmak üzere toplam 365 adet Oda ve Borsa bulunmaktadır ve mevzuatla kendilerine verilen pek çok görevi yerine getirmek için personel istihdamında bulunurlar. Buralarda istihdam edilen personel sayısı konusunda yayımlanmış resmi bir istatistik bulunmamakla birlikte bunların bağlı bulunduğu Türkiye Odalar, Borsalar ve Birlik Personeli Emekli Sandığı Vakfi'nın 2016 yılı Faaliyet Raporu ve 2018 Yılı İş Programı Bütçe kitapçığında, 2016 itibarıyla personel sayısının 6037 olduğu sonucuna ulaşılmıştır (TOBB, 2017:12). Bu kuruluşlardaki statü hukuku ile esnek hukuka tabi personel olmak üzere iki farklı personel rejim politikası, 5174 sayılı Kanunun yürürlüğe girmesiyle değişikliğe uğramii, esnek hukuka tabi personel rejim politikasının öne çıkmasına ve önem kazanmasına neden olmuştur.

Araştırmanın amacı; bu kuruluşlardaki personelin statü, istihdam edilme, yükselme, hukuki korunma, emeklilik, sicil işlemleri, mali özlük hakları ve görev tanımlarına dair uygulamaları karşılaştırmak, ulaşılan sonuçlar ve yapılan tespitlerin ortaya konması ile bu alana katkıda bulunabilmek, odalar ve borsalarda istihdam edilen personelin sorunlarını ortaya koyabilmek ve bu sorunların demografik özelliklerine göre farklılaşma durumunu incelemektir. Bu temel amaç doğrultusunda araştırmada, araştırmaya katılan odalar ve borsalar personelinin; "kurumsallaşma ve iç işleyiş̧e", "istihdama" ve "özlük hakları"na yönelik sorunlara yaklaşım düzeyleri cinsiyet, eğitim düzeyi, çalışılan kurum türü, kurumun bulunduğu bölge, kurumun yerleşim yeri, çalışma yllı, (statü) işe giriş tarihi, aylık ortalama maaş aralığ ve pozisyonlara göre farklılaşmakta mıdır? sorusunun cevabı aranmıştır.

\section{ARAŞTIRMANIN YÖNTEMİ VE SINIRLILIKLARI}

Odalar ve borsalarda 5590 sayılı Kanuna tabi (statü hukuku) ve 5174 sayılı Kanuna tabi personel (iş hukuku) ile dışarda hizmet satın alınma yoluyla çalıştırılan (taşeron) personele yönelik hazırlanmış anket soruları, kurum ve bölge sınırı gözetilmeksizin http://www.surveey.com/ sitesi üzerinden oluşturulan özel link adresi üzerinden dağıtılmak suretiyle cevaplandırılması istenmiş, anket katılımcıları bu link üzerinden soruları cevaplamak suretiyle ankete katılım sağlamışlardır.

Alan araştırmasında kullanılan anket soruları öncelikli olarak "kurumsallaşma ve iç işleyiş", "istihdam" ve "özlük hakları" olmak üzere 3 başlık altında kategorileştirilmiştir. Anket sorularının belirlenmesinde öncelikli olarak odalar ve borsalar personelinin tabi olduğu mevzuat temel alınmış, internette çeşitli kurum ve kuruluşlar ile şirketlerin kendi çalışanlarına yönelik uyguladığı anket soruları odalar ve borsalar çalışanlarına uyarlanmıştır.

Araştırmanın evreni odalar ve borsalarda yukarda bahsedildiği şekilde istihdam edilen 6037 kişidir. \%5 hata payı ve \%95 güven aralığı düzeyinde hesaplanan en az katılımcı sayısının üzerinde 739 kişinin katılımıyla gerçekleştirilen anket sonuçlarından elde edilen veriler SPSS (Statistical Package for Social Sciences) 23.0 istatistik programında işlenerek, elde edilen verilere ait frekans dağılımları ve hipotez sonuçları tablolar halinde verilmiştir. Anket soruları; cinsiyet, yaş, medeni durum, çocuk sayısı, eğitim düzeyi, çalışılan kurum türü, kurumun bulunduğu bölge, kurumun yerleşim yeri, çalışma yılı, (statï) işe giriş tarihi, son aldığı maaş aralığı, aylık ortalama maaş aralığı, pozisyon, kurumun toplam personel sayısı (taşeronlar hariç), kurumda dışardan hizmet alımı (taşeron) İle çalışan personel sayısı, son 4 yıl içerisinde kuruma alınan personel sayısı (taşeronlar hariç), son 4 yıl içerisinde kurumdan ayrılan personel sayısı (taşeronlar hariç) şeklinde demografik bilgileri içeren bağımlı değişkenleri içermektedir.

Araştırmada Likert ölçek modeli kullanılmıştır. Likert ölçek modeli, birey ve grupların tutum, eğilim ve görüşlerini ölçmek için Rensis Likert tarafından geliştirilen bir ölçek olup (Cramer ve Howitt, 2004:89; 
İslamoğlu ve Alnıaçık, 2016:175), uygulaması ve ölçmesi kolay olması sebebiyle sosyal bilimler, siyaset bilimi, psikoloji, pazarlama ve eğitim gibi alanlarda başvurulan bir tekniktir (Edmondson, 2017:128). Ankette, 34 adet kurumsallaşma ve iç işleyişe yönelik, 24 adet istihdama yönelik ve 28 adet özlük haklarına yönelik toplam 86 adet soru sorulmuş, katılımcılardan verilen önermelerle ilgili görüşlerini, çok olumludan çok olumsuza kadar sıralanan seçeneklerden belirtmeleri istenmiştir. Buna göre; (5) tamamen katılıyorum (4) kısmen katıliyorum, (3) kararsızım, (2) kısmen katılmıyorum, (1) hiç katılmıyorum şeklinde bir Likert ölçek modeli kullanılmıştır.

Likert ölçek modeli kullanılarak elde edilen veriler çapraz test (çapraz tablo analizi) ve Khi-kare testine tabi tutulmuştur. Çapraz tablo analizi parametrik-olmayan istatistiksel analizlerden biri olup, kullanılan değişkenlerin normal dağılım göstermediği ve örneklem sayısının küçük olduğu durumlarda kullanılır ve iki kategorik değişken arasındaki ilişkiyi incelemeyi sağlar (Uçar, 2006:85-112; İslamoğu ve Alnıçık, 2016:459; Toy ve Tosunoğlu, 2007:17). Araştırmamızda sağlanan verilerin parametrik veriler olmaması ve koşulların sağlanması nedeniyle Khi-kare testi uygulanmıştır. Bulguların çapraz test ve Khi-kare değerlendirilmesinde bağımsız değişkenlerden cinsiyet, eğitim düzeyi, çalışılan kurum türü, kurumun bulunduğu bölge, kurumun yerleşim yeri, (statü) işe giriş tarihi, aylık ortalama maaş aralığ 1 ve pozisyon ele alınmıştır. Bu araştırma; odalar ve borsalarda istihdam edilen tüm personelle, araştırmada kullanılan veri toplama araçlarından elde edilen verilerle ve araştırmada kullanılan istatistiki yöntemlerle sınırlıdır.

\section{ARASTTIRMA BULGULARI}

\subsection{ELDE EDILLEN VERILERE İLIŞKİN DEMOGRAFIKK BULGULAR}

Ankete katılılan katılımcıların demografik özelliklerini tespit etmek amacıyla hazırlanan 17 adet soru ve cevap seçenekleri ile bu sorulara verilen cevapların sayıları ve yüzdelik dağılımları tablo 1'de gösterilmiştir.

Tablo 2. Alan Araştırmasında Demoğrafik Özellikler

\begin{tabular}{|c|c|c|c|}
\hline Bağımsız Değişkenler & & Sayı & $\%$ \\
\hline \multirow{3}{*}{ Cinsiyetiniz } & Kadın & 279 & 37,75 \\
\hline & Erkek & 460 & 62,25 \\
\hline & Toplam & 739 & 100,00 \\
\hline \multirow{6}{*}{ Yaşınız } & 18-25 Yaş & 21 & 2,84 \\
\hline & 26-33 Yaş & 220 & 29,77 \\
\hline & 34-41 Yaş & 307 & 41,54 \\
\hline & 42-49 Yaş & 152 & 20,57 \\
\hline & 50 yaş ve üzeri & 39 & 5,28 \\
\hline & Toplam & 739 & 100,00 \\
\hline \multirow{3}{*}{ Medeni Durumunuz? } & Evli & 587 & 79,43 \\
\hline & Bekar & 152 & 20,57 \\
\hline & Toplam & 739 & 100,00 \\
\hline \multirow{6}{*}{ Çocuk Sayısı } & Yok & 211 & 28,55 \\
\hline & 1 & 237 & 32,07 \\
\hline & 2 & 217 & 29,36 \\
\hline & 3 & 57 & 7,71 \\
\hline & 4 ve üstü & 17 & 2,30 \\
\hline & Toplam & 739 & 100,00 \\
\hline $\begin{array}{c}\text { Eğitim Durumunuz } \\
\text { (En son Mezun Olduğunuz Okul)? }\end{array}$ & İlköğretim & 11 & 1,49 \\
\hline
\end{tabular}


Uluslararası Yönetim Akademisi Dergisi, 2020, C.3, S.1, ss.207-240

\begin{tabular}{|c|c|c|c|}
\hline & Ortaöğretim (lise) & 153 & 20,70 \\
\hline & Yüksek Okul (2 yıllık) & 87 & 11,77 \\
\hline & Fakülte (lisans) & 430 & 58,19 \\
\hline & Yüksek Lisans ve Üzeri & 58 & 7,85 \\
\hline & Toplam & 739 & 100,00 \\
\hline \multirow{6}{*}{ Kurumunuz } & Ticaret Odası & 153 & 20,70 \\
\hline & Ticaret ve Sanayi Odası & 323 & 43,71 \\
\hline & Sanayi Odası & 12 & 1,62 \\
\hline & Deniz Ticaret Odası & 16 & 2,17 \\
\hline & Ticaret Borsası & 235 & 31,80 \\
\hline & Toplam & 739 & 100,00 \\
\hline \multirow{8}{*}{ Kurumunuzun Bulunduğu Bölge } & Marmara & 153 & 20,70 \\
\hline & Ege & 170 & 23,00 \\
\hline & Akdeniz & 97 & 13,13 \\
\hline & Karadeniz & 120 & 16,24 \\
\hline & İç Anadolu & 91 & 12,31 \\
\hline & Doğu Anadolu & 41 & 5,55 \\
\hline & Güneydoğu Anadolu & 67 & 9,07 \\
\hline & Toplam & 739 & 100,00 \\
\hline \multirow{3}{*}{ Kurumunuzun Yerleşim Yeri } & İl & 422 & 57,10 \\
\hline & İlçe & 317 & 42,90 \\
\hline & Toplam & 739 & 100,00 \\
\hline \multirow{7}{*}{ Kaç Yıldır Bu Kurumda Çalışıyorsunuz } & $0-1$ yil & 52 & 7,04 \\
\hline & $2-8$ y1l & 288 & 38,97 \\
\hline & $9-15$ y1l & 205 & 27,74 \\
\hline & $16-20$ y1l & 101 & 13,67 \\
\hline & 21 ve daha fazla & 90 & 12,18 \\
\hline & Taşeron işçiyim (Dışardan Hizmet Satın Alma Yoluyla Çalışıyorum & 3 & 0,41 \\
\hline & Toplam & 739 & 100,00 \\
\hline \multirow{4}{*}{ İșe Girme Tarihiniz (Statünüz) } & 5590 sayılı Kanuna Tabiyim (1.6.2004 öncesi işe girdim) & 216 & 29,23 \\
\hline & 5174 sayılı Kanuna Tabiyim (1.6.2004 sonrası işe girdim & 511 & 69,15 \\
\hline & Taşeron İşçiyim (Dışardan Hizmet Satın Alma Yoluyla Çalışıyorum) & 12 & 1,62 \\
\hline & Toplam & 739 & 100,00 \\
\hline \multirow{3}{*}{ Son Aldığınız Maaş Aralığınız } & $1600 \mathrm{TL}-2000 \mathrm{TL}$ & 136 & 18,40 \\
\hline & $2001 \mathrm{TL}-2500 \mathrm{TL}$ & 165 & 22,33 \\
\hline & $2501 \mathrm{TL}-3000 \mathrm{TL}$ & 141 & 19,08 \\
\hline
\end{tabular}


AYDEMİR, Süleyman Ruhi - Türk Kamu Yönetiminde Ticaret Odaları ve Ticaret Borsaları Personeli Sorunu Araştırması

\begin{tabular}{|c|c|c|c|}
\hline & $3001 \mathrm{TL}-3500 \mathrm{TL}$ & 108 & 14,61 \\
\hline & 3501 TL-4500 TL & 115 & 15,56 \\
\hline & 4501 TL ve üzeri & 74 & 10,01 \\
\hline & Toplam & 739 & 100,00 \\
\hline \multirow{7}{*}{$\begin{array}{c}\text { Aylık Ortalama Maaş Aralığınız } \\
\text { (İkramiyeler, Mesailer,İlave Ödemeler Dahil) }\end{array}$} & $1600 \mathrm{TL}-2000 \mathrm{TL}$ & 94 & 12,72 \\
\hline & 2001 TL-2500 TL & 141 & 19,08 \\
\hline & 2501 TL-3000 TL & 134 & 18,13 \\
\hline & 3001 TL-3500 TL & 139 & 18,81 \\
\hline & 3501 TL-4500 TL & 140 & 18,94 \\
\hline & 4501 TL ve üzeri & 91 & 12,31 \\
\hline & Toplam & 739 & 100,00 \\
\hline \multirow{7}{*}{ Pozisyonunuz } & Genel Sekreter (veya vekili) & 109 & 14,75 \\
\hline & Genel Sekreter Yardımcısı, Birim Müdürü & 63 & 8,53 \\
\hline & Şef/Birim sorumlusu & 74 & 10,01 \\
\hline & Ticaret Sicili Müdürü/Yardımcısı & 114 & 15,43 \\
\hline & Diğer Personel & 373 & 50,47 \\
\hline & Taşeron işçiyim (Dışardan Hizmet Satın Alma Yoluyla Çalışıyorum) & 6 &, 81 \\
\hline & Toplam & 739 & 100,00 \\
\hline \multirow{7}{*}{$\begin{array}{l}\text { Kurumun toplam personel sayısı } \\
\text { (taşeronlar hariç) }\end{array}$} & Bilmiyorum & 12 & 1,62 \\
\hline & 1-10 Kişi & 298 & 40,32 \\
\hline & 11-15 Kişi & 107 & 14,48 \\
\hline & 16-25 Kişi & 141 & 19,08 \\
\hline & 26-35 Kişi & 45 & 6,09 \\
\hline & 36 ve üstü & 136 & 18,40 \\
\hline & Toplam & 739 & 100,00 \\
\hline \multirow{8}{*}{$\begin{array}{c}\text { Kurumda Dişardan Hizmet Alımı (taşeron) İle } \\
\text { Çalışan Personel Sayısı }\end{array}$} & Bilmiyorum & 85 & 11,50 \\
\hline & Yok & 359 & 48,58 \\
\hline & 1-3 Kişi & 144 & 19,49 \\
\hline & 4-7 Kişi & 77 & 10,42 \\
\hline & 8-10 Kişi & 46 & 6,22 \\
\hline & 11-16 Kişi & 19 & 2,57 \\
\hline & 17 ve üstü & 9 & 1,22 \\
\hline & Toplam & 739 & 100,00 \\
\hline \multirow{3}{*}{$\begin{array}{l}\text { Son } 4 \text { yıl içerisinde Kuruma alınan personel sayısı } \\
\text { (taşeronlar hariç) }\end{array}$} & Bilmiyorum & 81 & 10,96 \\
\hline & 0 kişi & 82 & 11,10 \\
\hline & 1-4 Kişi & 415 & 56,16 \\
\hline
\end{tabular}




\begin{tabular}{|c|c|c|c|}
\hline & 5-8 kişi & 93 & 12,58 \\
\hline & 9 ve üstü & 68 & 9,20 \\
\hline & Toplam & 739 & 100,00 \\
\hline \multirow{6}{*}{$\begin{array}{c}\text { Son } 4 \text { yıl içerisinde Kurumdan ayrılan personel sayısı } \\
\text { (taşeronlar hariç) }\end{array}$} & Bilmiyorum & 89 & 12,04 \\
\hline & 0 Kişi & 140 & 18,94 \\
\hline & 1-3 Kişi & 372 & 50,34 \\
\hline & 4-7 Kişi & 101 & 13,67 \\
\hline & 8 ve Üstü & 37 & 5,01 \\
\hline & Toplam & 739 & 100,00 \\
\hline
\end{tabular}

Yapılan araştırmaya göre ankete katılanların, 729 kişinin çoğunluğunu 460 kişi ile erkekler oluşturmakta, katılanların çoğunluğunu genç nüfus oluşturmaktadır. Oldukça yüksek çoğunluğunu evliler oluşturmakta, 1 ve 2 çocuk sahibi ile çocuk sahibi olmayanların yoğunluğu oluşturduğu gözlemlenmiştir. 430 kişinin $\% 58,18$ kişi ile lisans mezunu olduğu, bunu 153 kişi ve $\% 20,70$ ile lise mezunlarının takip ettiği, 323 kişinin \%43,70 ile Ticaret ve Sanayi Odalarında çalıştığı, bunu 235 kişi ve \% 31,79 ile Ticaret Borsalarında çalışanların olduğu, bölgesel olarak en yüksek katılım Marmara Bölgesinden, en düşük katılım ise Doğu Anadolu Bölgesindendir, çalıştıkları kurumların bulundukları yerleşim yerleri bağlamında dengeli bir dağılım söz konusudur.

Ankete katılan personelin çalışma yılının 2-8 yıl ve 9-15 yıl arasında yoğunlaştığı görülmüştür. Çalışma yılı olarak ankete katılanlar arasında dengeli bir dağılım vardır. Ankete katılanların büyük bir kısmının 01.06.2004 tarihinden sonra yani 5174 sayılı Kanuna tabi olduğu görülmektedir. Ankete katılanların aldıkları maaşa göre göre dağılımında dengeli bir dağılım olduğu görülmektedir. Aylık ortalama maaş aralı̆̆ dağılımı da aylık maaş aralığı gibi dengelidir. Aylık ortalama maaş oranlarının aylık maaş oranlarına göre yükselmesinin sebebi personelin ikramiye, ek ücret gibi ödenditileri de almasıdır. Ankete katılanların oldukça yüksek kısmı 373 kişi ve \%50,47 oranla diğer personelden oluşmaktadır. Ankete katılanların çalıştıkları kurumlarda çalışan personel sayısına göre dağılımında 1-10 kişi ve 16-25 kişi yoğunluğu gözlemlenmiştir. 12 personel çalıştığı kurumda kaç personel çalıştığını bilmemektedir.

\subsection{ALAN ARAŞTIRMASI ANALIZí}

Anket formunda personel sorunlarını ölçmeye yönelik 111 tane ifade kullanılmıştır. 5'li liker ölçeği kullanılarak hazırlanan ifadeler ve bu ifadelerin tercih sayıları ile yüzdelikleri toplu olarak tablo halinde gösterilmiştir.

Tablo 3. Alan Araştırmasında Kullanılan Değişkenler

\begin{tabular}{|c|c|c|c|c|c|c|c|c|c|c|}
\hline \multirow[b]{2}{*}{ KURUMSALLAŞMA VE İÇ İŞLEYISŞE İLISŞKİN SORULAR } & \multicolumn{2}{|c|}{$\begin{array}{l}\text { 5- Tamamen } \\
\text { Katılıyorum }\end{array}$} & \multicolumn{2}{|c|}{$\begin{array}{l}\text { 4- Kismen } \\
\text { Katiliyorum }\end{array}$} & \multicolumn{2}{|c|}{$\begin{array}{l}\text { 3- } \\
\text { Kararsızım }\end{array}$} & \multicolumn{2}{|c|}{$\begin{array}{l}\text { 2- Kismen } \\
\text { Katılmiyorum }\end{array}$} & \multicolumn{2}{|c|}{$\begin{array}{l}\text { 1- Hiç } \\
\text { Katılmıorum }\end{array}$} \\
\hline & Sayı & $\%$ & Sayı & $\%$ & Sayı & $\%$ & Sayı & $\%$ & Sayı & $\%$ \\
\hline Kurumumun misyon,vizyon,temel değerleri,strateji ve hedeflerinden haberdarım & 508 & 68 & 157 & 21 & 35 & 4 & 18 & 2 & 21 & 2 \\
\hline Yönetim Kurulu kurumun yasal mevzuatına hâkimdir & 230 & 31 & 242 & 32 & 111 & 15 & 78 & 10 & 78 & 10 \\
\hline Yönetim Kurulu kurumu kendi işyerleri gibi yönetmektedir. & 233 & 31 & 207 & 28 & 107 & 14 & 70 & 9 & 122 & 16 \\
\hline Yönetim Kurulu, personeli kendi özel işlerinde de kullanmaktadır & 122 & 16 & 140 & 18 & 69 & 9 & 100 & 13 & 308 & 41 \\
\hline Yönetim Kurulu, kurum bütçesini kullanırken tasarrufa riayet eder & 293 & 39 & 216 & 29 & 110 & 14 & 57 & 7 & 63 & 8 \\
\hline $\begin{array}{l}\text { Yaptığım işlerle ilgili görev tanımım ve sorumluluklarım açık bir şekilde } \\
\text { dokümanlarla belirlenmiştir }\end{array}$ & 424 & 57 & 187 & 25 & 51 & 6 & 42 & 5 & 35 & 4 \\
\hline Amirim konumu ve görevi ile ilgili yetkinlik ve yeterliliğe sahiptir & 356 & 48 & 220 & 29 & 72 & 9 & 40 & 5 & 51 & 6 \\
\hline İşimle ilgili sorunlarımı amirim ile paylaşabiliyorum & 386 & 52 & 190 & 25 & 63 & 8 & 46 & 6 & 54 & 7 \\
\hline İşimle ilgili sorunlarımı Yönetim Kurulu ile paylaşabiliyorum & 167 & 22 & 174 & 23 & 131 & 17 & 88 & 11 & 179 & 24 \\
\hline
\end{tabular}


AYDEMİ, Süleyman Ruhi - Türk Kamu Yönetiminde Ticaret Odaları ve Ticaret Borsaları Personeli Sorunu Araştırması

\begin{tabular}{|c|c|c|c|c|c|c|c|c|c|c|}
\hline Sorumluklarım ölçüsünde yetkim bulunmaktadır. & 299 & 40 & 244 & 33 & 92 & 12 & 53 & 7 & 51 & 6 \\
\hline İşimle ilgili en küçük aksaklıkta amirim tarafından bana olumsuz tavır alınmaktadır. & 99 & 13 & 130 & 17 & 108 & 14 & 151 & 20 & 251 & 33 \\
\hline $\begin{array}{l}\text { İşimle ilgili en küçük aksaklıkta Yönetim Kurulu tarafından bana olumsuz tavır } \\
\text { alınmaktadır. }\end{array}$ & 111 & 15 & 133 & 17 & 104 & 14 & 133 & 17 & 258 & 34 \\
\hline Fırsat ve imkânlar adil ve şeffaf olarak tüm çalışanlara sunulmaktadır. & 173 & 23 & 155 & 20 & 125 & 16 & 77 & 10 & 209 & 28 \\
\hline Başarılarım amirim tarafından takdir edilmektedir. & 186 & 25 & 218 & 29 & 117 & 15 & 91 & 12 & 127 & 17 \\
\hline Başarılarım Yönetim Kurulu tarafından takdir edilmektedir & 141 & 19 & 182 & 24 & 146 & 19 & 86 & 11 & 184 & 24 \\
\hline $\begin{array}{l}\text { Yönetim Kurulu, çalışanların iş yerindeki sorunlarının yanı sıra iş yeri dışındaki } \\
\text { sorunlarıyla ilgilenir. }\end{array}$ & 91 & 12 & 155 & 20 & 134 & 18 & 103 & 13 & 256 & 34 \\
\hline $\begin{array}{l}\text { Amirim, çalışanların iş yerindeki sorunlarının yanı sıra iş yeri dışındaki sorunlarıyla } \\
\text { ilgilenir }\end{array}$ & 174 & 23 & 194 & 26 & 122 & 16 & 97 & 13 & 152 & 20 \\
\hline Yaptığım işte tüm potansiyelimi ve yaratıcılığımı kullanabiliyorum & 278 & 37 & 248 & 33 & 111 & 15 & 53 & 7 & 49 & 6 \\
\hline $\begin{array}{l}\text { Kurumumuzda çalışanlarla ilgili kararlar, çalışanların katılımıyla demokratik bir } \\
\text { şekilde alınır. }\end{array}$ & 127 & 17 & 162 & 21 & 146 & 19 & 78 & 10 & 226 & 30 \\
\hline Kurumumuzda çalışanların dile getirdiği şikâyet ve öneriler dikkate alınmaktadır & 153 & 20 & 226 & 30 & 121 & 16 & 100 & 13 & 139 & 18 \\
\hline $\begin{array}{l}\text { Yönetim Kurulunun sergilediği tutum ve davranışlar, çalışanları motive edici } \\
\text { yöndedir }\end{array}$ & 138 & 18 & 186 & 25 & 142 & 19 & 101 & 13 & 172 & 23 \\
\hline Amirimin sergilediği tutum ve davranışlar, çalışanları motive edici yöndedir. & 195 & 26 & 210 & 28 & 130 & 17 & 85 & 11 & 119 & 16 \\
\hline $\begin{array}{l}\text { Kurumumda görev, yetki ve sorumluluklar birimler arasında dengeli bir şekilde } \\
\text { paylaştırılmıştır. }\end{array}$ & 131 & 17 & 188 & 25 & 135 & 18 & 103 & 13 & 182 & 24 \\
\hline Kurumumda personel, birimler arasında dengeli ve adil bir biçimde dağıtılmıştır. & 149 & 20 & 184 & 24 & 142 & 19 & 97 & 13 & 167 & 22 \\
\hline $\begin{array}{l}\text { Yönetim Kurulu çalışanların mesleklerinde gelişmeleri (hizmet içi eğitimlere } \\
\text { katılımlarda, yüksek lisans yapmada vs.) için gerekli desteği verir }\end{array}$ & 196 & 26 & 189 & 25 & 158 & 21 & 67 & 9 & 129 & 17 \\
\hline $\begin{array}{l}\text { Yönetim Kurulu iyi performans gösteren personeli aylıkla veya takdir, teşekkür vs } \\
\text { ile ödüllendirir. }\end{array}$ & 122 & 16 & 146 & 19 & 121 & 16 & 89 & 12 & 261 & 35 \\
\hline Kurumumda yaptığım iş için gerekli yetki, sorumluluk ve inisiyatif tanınmaktadır & 202 & 27 & 265 & 35 & 121 & 16 & 83 & 11 & 68 & 9 \\
\hline Kurumumda, çalışanların duygu ve değerlerine saygı gösterilmektedir. & 195 & 26 & 228 & 30 & 124 & 16 & 78 & 10 & 114 & 15 \\
\hline $\begin{array}{l}\text { Yönetim Kurulu, işimi mevzuat çerçevesinde en iyi şekilde yapmam için beni } \\
\text { serbest bırakır }\end{array}$ & 221 & 29 & 237 & 32 & 139 & 18 & 71 & 9 & 71 & 9 \\
\hline $\begin{array}{l}\text { Amirim, işimi mevzuat talimatlar çerçevesinde en iyi şekilde yapmam için beni } \\
\text { serbest bırakır }\end{array}$ & 271 & 36 & 254 & 34 & 99 & 13 & 60 & 8 & 55 & 7 \\
\hline Sorun çıktığında, birbirimizi suçlamak yerine çözümü araştırmayı tercih ederiz & 253 & 34 & 208 & 28 & 123 & 16 & 62 & 8 & 93 & 12 \\
\hline $\begin{array}{l}\text { Yönetim Kurulundan işimle ilgili görevden uzaklaştırma şeklinde tehdit } \\
\text { almaktayım. }\end{array}$ & 52 & 7 & 69 & 9 & 65 & 8 & 70 & 9 & 483 & 65 \\
\hline $\begin{array}{l}\text { Yönetim Kurulundan dolaylı veya dolaysız olarak işime son verilme şeklinde tehdit } \\
\text { almaktayım. }\end{array}$ & 54 & 7 & 65 & 8 & 63 & 8 & 87 & 11 & 470 & 63 \\
\hline Başarılarım iş arkadaşlarım tarafından takdir edilmektedir. & 198 & 26 & 233 & 31 & 156 & 21 & 65 & 8 & 87 & 11 \\
\hline \multicolumn{11}{|l|}{ İSTİHDAMA İLİŞKİN SORULAR } \\
\hline Kurumumun ne iş yaptığını bilerek burda çalışmaya başladım & 349 & 47 & 230 & 31 & 53 & 7 & 57 & 7 & 50 & 6 \\
\hline Kuruma personel alınacağı zaman fikrim alınmaktadır. & 89 & 12 & 108 & 14 & 66 & 8 & 71 & 9 & 405 & 54 \\
\hline İşimi kaybetme endişesi taşımaktayım. & 167 & 22 & 138 & 18 & 115 & 15 & 110 & 14 & 209 & 28 \\
\hline $\begin{array}{l}\text { Kuruma yeni alınacak personel için istihdamın nasıl sağlanacağına dair bir yöntem } \\
\text { veya metod mevcuttur. Bunun dışında istihdam sağlanmaz. }\end{array}$ & 164 & 22 & 156 & 21 & 165 & 22 & 68 & 9 & 186 & 25 \\
\hline Bu Kurumumun bir çalışanı olmaktan memnunum. & 356 & 48 & 228 & 30 & 81 & 10 & 37 & 5 & 37 & 5 \\
\hline
\end{tabular}




\begin{tabular}{|c|c|c|c|c|c|c|c|c|c|c|}
\hline Yaptığım işten zevk alıyorum ve işimi seviyorum. & 418 & 56 & 198 & 26 & 67 & 9 & 25 & 3 & 31 & 4 \\
\hline Bilgi ve yeteneklerime uygun bir iş yapmaktayım. & 389 & 52 & 201 & 27 & 88 & 11 & 31 & 4 & 30 & 4 \\
\hline Kurumumda personelin problemleri süratle çözümlenmektedir. & 145 & 19 & 194 & 26 & 170 & 23 & 99 & 13 & 131 & 17 \\
\hline Yönetim Kuruluna sorunlarımı iletme imkânı bulurum & 193 & 26 & 193 & 26 & 128 & 17 & 90 & 12 & 135 & 18 \\
\hline Amirime sorunlarımı iletme imkânı bulurum & 352 & 47 & 214 & 28 & 80 & 10 & 44 & 5 & 49 & 6 \\
\hline İşe başladığımda hizmet içi eğitimden geçtim & 237 & 32 & 159 & 21 & 56 & 7 & 89 & 12 & 198 & 26 \\
\hline Kuruma personel alınırken KPSS puanı şart olmalıdır & 216 & 29 & 115 & 15 & 153 & 20 & 44 & 5 & 211 & 28 \\
\hline Aldığım eğitime uygun bir bölümde çalışsıorum. & 323 & 43 & 211 & 28 & 83 & 11 & 45 & 6 & 77 & 10 \\
\hline $\begin{array}{l}\text { Çalışma ortamım ve çalı̧̧a koşullarım ile ilgili yapılacak düzenlemelerde } \\
\text { görüşüme başvurulur. }\end{array}$ & 193 & 26 & 217 & 29 & 110 & 14 & 68 & 9 & 151 & 20 \\
\hline Çalıştığım bölümün işleyişi konusunda önerilerim dikkate alınır. & 241 & 32 & 269 & 36 & 79 & 10 & 67 & 9 & 83 & 11 \\
\hline Kurumum kariyer planlarımı gerçekleştirmemde bana olanaklar sunmaktadır. & 147 & 19 & 182 & 24 & 178 & 24 & 81 & 10 & 151 & 20 \\
\hline Çalıştığım kurumdan ayrılmayı hiç düşünmem & 265 & 35 & 177 & 23 & 150 & 20 & 65 & 8 & 82 & 11 \\
\hline İşe alınmamda Yönetim Kurulunun katkısı olmuştur. & 236 & 31 & 189 & 25 & 100 & 13 & 64 & 8 & 150 & 20 \\
\hline Kuruma personel alınırken Yönetim Kurulu yakını olmak öncelik tercih sebebidir & 184 & 24 & 129 & 17 & 117 & 15 & 96 & 12 & 213 & 28 \\
\hline Çalışabileceğim en iyi kuruluşun yine de burası olduğunu düşünüyorum. & 264 & 35 & 189 & 25 & 168 & 22 & 52 & 7 & 66 & 8 \\
\hline Son 1 yıl içerisinde istifa etmeyi düşündüm. & 127 & 17 & 93 & 12 & 89 & 12 & 60 & 8 & 370 & $\mathbf{5 0}$ \\
\hline Sebepsiz yere işten çıkarılan arkadaşımız bulunmaktadır. & 81 & 10 & 50 & 6 & 80 & 10 & 66 & 8 & 462 & 62 \\
\hline Yönetim değişikleri beni tedirgin eder & 241 & 32 & 150 & 20 & 118 & 15 & 70 & 9 & 160 & 21 \\
\hline Çalışma yaşamımda mobbingle karşı karşıya kalmaktayım & 105 & 14 & 108 & 14 & 159 & 21 & 85 & 11 & 282 & 38 \\
\hline \multicolumn{11}{|l|}{ ÖZLÜK HAKLARINA İLISSSİN SORULAR } \\
\hline Haklarım, ödev ve sorumluluklarımla ilgili mevzuatı biliyorum. & 415 & 56 & 248 & 33 & 39 & 5 & 17 & 2 & & \\
\hline Geçim sıkıntısı çekiyorum. & 209 & 28 & 208 & 28 & 89 & 12 & 105 & 14 & 128 & 17 \\
\hline Personel arasındaki maaş aralıkları dikkat çekici düzeydedir. & 271 & 36 & 170 & 23 & 100 & 13 & 90 & 12 & 108 & 14 \\
\hline $\begin{array}{l}\text { Personele verilen maaşlar yetki, görev ve sorumluluk dikkate alınarak } \\
\text { belirlenmektedir. }\end{array}$ & 166 & 22 & 161 & 21 & 118 & 15 & 81 & 10 & 213 & 28 \\
\hline Başka Oda/Borsalarda benimle aynı işi yapan daha fazla özlük haklarına sahiptir. & 306 & 41 & 145 & 19 & 189 & 25 & 32 & 4 & 67 & 9 \\
\hline Y1llık izinlerimi istediğim zaman kullanabiliyorum. & 334 & 45 & 191 & 25 & 62 & 8 & 52 & 7 & 100 & 13 \\
\hline Y1llık izinlerimi tam olarak kullanabiliyorum. & 358 & 48 & 164 & 22 & 43 & 5 & 50 & 6 & 124 & 16 \\
\hline Mazeret İzinlerimi istediğim zaman kullanabiliyorum. & 369 & 49 & 177 & 23 & 59 & 7 & 43 & 5 & 91 & 12 \\
\hline Mesaiden tam zamanında çıkamıyorum. & 172 & 23 & 158 & 21 & 70 & 9 & 119 & 16 & 220 & 29 \\
\hline İkramiyelerimi, fazla mesai ücretlerimi zamanında ve eksiksiz alıyorum. & 312 & 42 & 103 & 13 & 59 & 7 & 56 & 7 & 209 & 28 \\
\hline Hastalandığımda hastaneye gidip tedavide problem yaşıyorum. & 239 & 32 & 145 & 19 & 43 & 5 & 67 & 9 & 245 & 33 \\
\hline Şehir dışında hastalandığımda hastaneye gidip tedavide problem yaşıyorum. & 330 & 44 & 119 & 16 & 102 & 13 & 47 & 6 & 141 & 19 \\
\hline Hastalık raporu aldığımda buna ilişkin iznimi rahatlıkla kullanabiliyorum. & 373 & $\mathbf{5 0}$ & 137 & 18 & 106 & 14 & 35 & 4 & 88 & 11 \\
\hline Kurumumda yapılan atama ve terfilerde liyakate dikkat edilmektedir. & 156 & 21 & 187 & 25 & 175 & 23 & 68 & 9 & 153 & 20 \\
\hline $\begin{array}{l}\text { Yönetim tarafindan çalşsanları ödüllendirme (teşekkür yazıları, ek ödeme ilave } \\
\text { puanı, vb.) mekanizmaları işletilmektedir. }\end{array}$ & 122 & 16 & 125 & 16 & 124 & 16 & 83 & 11 & 285 & 38 \\
\hline
\end{tabular}


AYDEMİ, Süleyman Ruhi - Türk Kamu Yönetiminde Ticaret Odaları ve Ticaret Borsaları Personeli Sorunu Araştırması

\begin{tabular}{|c|c|c|c|c|c|c|c|c|c|c|}
\hline Yazılı ve sözlü cezalandırmalarda personel arasında ayrım yapılmaktadır. & 146 & 19 & 94 & 12 & 148 & 20 & 84 & 11 & 267 & 36 \\
\hline Disiplin uygulamaları dökümanlarla açık ve net olarak bildirilmiştir. & 248 & 33 & 174 & 23 & 171 & 23 & 48 & 6 & 98 & 13 \\
\hline $\begin{array}{l}\text { Her türlü ödüllendirme ve terfilerde bireysel performans değerlendirme sonuçları } \\
\text { esas alınmaktadır. }\end{array}$ & 139 & 18 & 133 & 17 & 157 & 21 & 86 & 11 & 224 & 30 \\
\hline En küçük hatamda bile sözlü ve yazılı uyarıyla karşılaşıyorum & 100 & 13 & 107 & 14 & 107 & 14 & 134 & 18 & 291 & 39 \\
\hline Yönetim Kurulu kurumdan ayrılmadan işyerinden ayrılamıyorum. & 179 & 24 & 102 & 13 & 68 & 9 & 78 & 10 & 312 & 42 \\
\hline Bir sendikaya üye olma hakkımın olduğunu biliyorum. & 120 & 16 & 72 & 9 & 158 & 21 & 43 & 5 & 346 & 46 \\
\hline Bir Sendikaya üyeyim. & 7 & 0 & 5 & 0 & 26 & 3 & 16 & 2 & 685 & 92 \\
\hline Faydasına inanmadığım için sendikaya üye olmadım. & 152 & 20 & 28 & 3 & 190 & 25 & 38 & 5 & 331 & 44 \\
\hline Sendikaya üye olursam işimle ilgili sıkıntı yaşarım. & 186 & 25 & 53 & 7 & 223 & 30 & 37 & 5 & 240 & 32 \\
\hline Başka bir Odaya/Borsaya tayin hakkımın olmasını isterdim. & 476 & 64 & 83 & 11 & 77 & 10 & 15 & 2 & 88 & 11 \\
\hline 5590 Sayılı Kanuna tabi olmaktan memnunum/tabi olmayı isterdim. & 362 & 48 & 73 & 9 & 168 & 22 & 14 & 1 & 122 & 16 \\
\hline 5174 say1lı Kanuna tabi olmaktan memnunum/tabi olmayı isterdim. & 141 & 19 & 76 & 10 & 175 & 23 & 42 & 5 & 305 & 41 \\
\hline Devlette Kamu çalıșanı statüsüne alınmak isterdim. & 611 & 82 & 48 & 6 & 48 & 6 & 5 & 0 & 27 & 3 \\
\hline
\end{tabular}

\subsubsection{Anket Güvenirlilik Testi}

Elde edilen verilerin analizin yapılmasından önce, verileri elde etmek için uygulanan anketin güvenilir olup olmadığı tespit edilmiştir. Güvenirlik, ele alınan ölçüm aracının benzer şartlarda benzer girdilerle yapılan değişik ölçümlerde benzer sonuçları vermesidir (İslamoğu ve Alnıaçık, 2016:291). En çok "Cronbach' alpha" testinin kullanıldığı güvenirlilik analizleri sonucunda bulunan değerler (Kayış, 2010:405);

- $0,00<$ a 0.40 ise ölçek güvenilir değildir,

- $0.40<\mathrm{a} 0.60$ ise ölçeğin güvenirliliği düşük,

- $0.60<$ a 0.80 ise ölçek oldukça güvenilir ve

- $0.80<$ a 1.00 ise ölçek yüksek derecede güvenirliğe sahiptir denir (Kayış, 2010:405; İslamoğu ve Alnıaçık, 2016:292).

Tablo 4. Anket Güvenilirlik Analizi

\begin{tabular}{|c|c|c|c|}
\hline \multicolumn{4}{|c|}{ Case Processing Summary } \\
\hline \multirow{3}{*}{ Cases } & Valid & N & $\%$ \\
\hline & Excluded $^{\mathrm{a}}$ & 0 & 0,0 \\
\cline { 2 - 4 } & Total & 739 & 100,0 \\
\hline \multirow{4}{*}{ Reliability Statistics } \\
\hline Cronbach's Alpha & N of Items & \\
\hline $\mathbf{8 9 3}$ & 86 & & \\
\hline
\end{tabular}

Araştırmamızda uygulanan anket için yapılan güvenirlilik analizi sonuçlarına göre Cronbach's Alpha değeri 0,893 çıktığından anketin yüksek derecede güvenilir olduğu söylenebilir. 


\subsubsection{Bağımlı ve Bağımsız Değişkenlerin Frekans Dağılımları}

Odalar ve borsalar personel sorunları anketinde kullanılan bağımsız değişkenlerin frekans dağılımları aşağıdaki gibi hazırlanmıştır. Bağımlı değişkenlerde kullanılan 5'li likert ölçeklerden "Tamamen Katılıyorum" ile "Kısmen Katıllyorum" ve "Hiç Katılmıyorum" ile "Kısmen Katıllyorum" ölçeklerinin sorular niteliğinde birbirine yakın olması sebebiyle, ölçekler 3'e indirilerek "Katıllyorum", "Kararsızım" ve "Katılmıyorum" şeklinde ele alınarak frekans dağılımları yeniden hesaplanmış ve aşağıdaki sonuçlar elde edilmiştir.

Tablo 5. Bağımlı Değişkenlerin 3'lü Frekans Dağılımları

\begin{tabular}{|c|c|c|c|}
\hline \multirow[t]{2}{*}{ Bağımlı Değişkenler } & \multicolumn{3}{|c|}{ 3'lü li Frekans Dağılımları } \\
\hline & Ölçekler & Sayı & $\%$ \\
\hline \multirow{4}{*}{ KR (Kurumumun misyon,vizyon,temel değerleri,strateji ve hedeflerinden haberdarım) } & Katıliyorum & 665 & 89,99 \\
\hline & Kararsızım & 35 & 4,74 \\
\hline & Katılmiyorum & 39 & 5,28 \\
\hline & Toplam & 739 & 100,00 \\
\hline \multirow{4}{*}{ KR (Yönetim Kurulu kurumun yasal mevzuatına hâkimdir) } & Katıliyorum & 472 & 63,87 \\
\hline & Kararsızım & 111 & 15,02 \\
\hline & Katılmiyorum & 156 & 21,11 \\
\hline & Toplam & 739 & 100,00 \\
\hline \multirow{4}{*}{ KR (Yönetim Kurulu kurumu kendi işyerleri gibi yönetmektedir.) } & Katıliyorum & 440 & 59,54 \\
\hline & Kararsizim & 107 & 14,48 \\
\hline & Katılmiyorum & 192 & 25,98 \\
\hline & Toplam & 739 & 100,00 \\
\hline \multirow{4}{*}{ KR (Yönetim Kurulu, personeli kendi özel işlerinde de kullanmaktadır) } & Katıliyorum & 262 & 35,45 \\
\hline & Kararsızım & 69 & 9,34 \\
\hline & Katılmiyorum & 408 & 55,21 \\
\hline & Toplam & 739 & 100,00 \\
\hline \multirow{4}{*}{ KR (Yönetim Kurulu, kurum bütçesini kullanırken tasarrufa riayet eder) } & Katıliyorum & 472 & 69,62 \\
\hline & Kararsızım & 110 & 16,22 \\
\hline & Katılmiyorum & 96 & 14,16 \\
\hline & Toplam & 678 & 100,00 \\
\hline \multirow{4}{*}{$\begin{array}{l}\text { KR (Yaptığım işlerle ilgili görev tanımım ve sorumluluklarım açık bir şekilde dokümanlarla } \\
\text { belirlenmiştir) }\end{array}$} & Katıliyorum & 611 & 82,68 \\
\hline & Kararsızım & 51 & 6,90 \\
\hline & Katılmiyorum & 77 & 10,42 \\
\hline & Toplam & 739 & 100,00 \\
\hline \multirow{4}{*}{ KR (Amirim konumu ve görevi ile ilgili yetkinlik ve yeterliliğe sahiptir) } & Katıliyorum & 576 & 77,94 \\
\hline & Kararsızım & 72 & 9,74 \\
\hline & Katılmiyorum & 91 & 12,31 \\
\hline & Toplam & 739 & 100,00 \\
\hline
\end{tabular}


AYDEMİ, Süleyman Ruhi - Türk Kamu Yönetiminde Ticaret Odaları ve Ticaret Borsaları Personeli Sorunu Araştırması

\begin{tabular}{|c|c|c|c|}
\hline \multirow{4}{*}{ KR (İşimle ilgili sorunlarımı amirim ile paylaşabiliyorum) } & Katıliyorum & 576 & 77,94 \\
\hline & Kararsızım & 63 & 8,53 \\
\hline & Katılmiyorum & 100 & 13,53 \\
\hline & Toplam & 739 & 100,00 \\
\hline \multirow{4}{*}{ KR (İşimle ilgili sorunlarımı Yönetim Kurulu ile paylaşabiliyorum) } & Katıliyorum & 341 & 46,14 \\
\hline & Kararsızım & 131 & 17,73 \\
\hline & Katılmiyorum & 267 & 36,13 \\
\hline & Toplam & 739 & 100,00 \\
\hline \multirow{4}{*}{ KR (Sorumluklarım ölçüsünde yetkim bulunmaktadır.) } & Katıliyorum & 543 & 73,48 \\
\hline & Kararsızım & 92 & 12,45 \\
\hline & Katılmiyorum & 104 & 14,07 \\
\hline & Toplam & 739 & 100,00 \\
\hline \multirow{4}{*}{ KR (İşimle ilgili en küçük aksaklıkta amirim tarafından bana olumsuz tavır alınmaktadır.) } & Katıliyorum & 229 & 30,99 \\
\hline & Kararsızım & 108 & 14,61 \\
\hline & Katılmiyorum & 402 & 54,40 \\
\hline & Toplam & 739 & 100,00 \\
\hline \multirow{4}{*}{ KR (İşimle ilgili en küçük aksaklıkta Yönetim Kurulu tarafından bana olumsuz tavır alınmaktadır.) } & Katıliyorum & 244 & 33,02 \\
\hline & Kararsızım & 104 & 14,07 \\
\hline & Katılmiyorum & 391 & 52,91 \\
\hline & Toplam & 739 & 100,00 \\
\hline \multirow{4}{*}{ KR (Fırsat ve imkânlar adil ve şeffaf olarak tüm çalışanlara sunulmaktadır.) } & Katılıyorum & 328 & 44,38 \\
\hline & Kararsızım & 125 & 16,91 \\
\hline & Katılmiyorum & 286 & 38,70 \\
\hline & Toplam & 739 & 100,00 \\
\hline \multirow{4}{*}{ KR (Başarılarım amirim tarafından takdir edilmektedir.) } & Katıliyorum & 404 & 54,67 \\
\hline & Kararsızım & 117 & 15,83 \\
\hline & Katılmiyorum & 218 & 29,50 \\
\hline & Toplam & 739 & 100,00 \\
\hline \multirow{4}{*}{ KR (Başarılarım Yönetim Kurulu tarafından takdir edilmektedir) } & Katılıyorum & 323 & 43,71 \\
\hline & Kararsızım & 146 & 19,76 \\
\hline & Katılmiyorum & 270 & 36,54 \\
\hline & Toplam & 739 & 100,00 \\
\hline \multirow{4}{*}{$\begin{array}{l}\text { KR (Yönetim Kurulu, çalışanların iş yerindeki sorunlarının yanı sıra iş yeri dışındaki sorunlarıyla } \\
\text { ilgilenir.) }\end{array}$} & Katılıyorum & 246 & 33,29 \\
\hline & Kararsızım & 134 & 18,13 \\
\hline & Katılmıyorum & 359 & 48,58 \\
\hline & Toplam & 739 & 100,00 \\
\hline
\end{tabular}




\begin{tabular}{|c|c|c|c|}
\hline \multirow{4}{*}{ KR (Amirim, çalışanların iş yerindeki sorunlarının yanı sıra iş yeri dışındaki sorunlarıyla ilgilenir) } & Katıliyorum & 368 & 49,80 \\
\hline & Kararsızım & 122 & 16,51 \\
\hline & Katılmiyorum & 249 & 33,69 \\
\hline & Toplam & 739 & 100,00 \\
\hline \multirow{4}{*}{ KR (Yaptığım işte tüm potansiyelimi ve yaratıcılığımı kullanabiliyorum) } & Kat1liyorum & 526 & 71,18 \\
\hline & Kararsızım & 111 & 15,02 \\
\hline & Katılmiyorum & 102 & 13,80 \\
\hline & Toplam & 739 & 100,00 \\
\hline \multirow{4}{*}{$\begin{array}{l}\text { KR (Kurumumuzda çalışanlarla ilgili kararlar, çalışanların katılımıyla demokratik bir şekilde } \\
\text { alınır.) }\end{array}$} & Kat1liyorum & 289 & 39,11 \\
\hline & Kararsızım & 146 & 19,76 \\
\hline & Kat1lmiyorum & 304 & 41,14 \\
\hline & Toplam & 739 & 100,00 \\
\hline \multirow{4}{*}{ KR (Kurumumuzda çalışanların dile getirdiği şikâyet ve öneriler dikkate alınmaktadır) } & Kat1liyorum & 379 & 51,29 \\
\hline & Kararsızım & 121 & 16,37 \\
\hline & Katılmiyorum & 239 & 32,34 \\
\hline & Toplam & 739 & 100,00 \\
\hline \multirow{4}{*}{ KR (Yönetim Kurulunun sergilediği tutum ve davranışlar, çalışanları motive edici yöndedir) } & Kat1liyorum & 0 & 0,00 \\
\hline & Kararsızım & 142 & 34,22 \\
\hline & Katılmiyorum & 273 & 65,78 \\
\hline & Toplam & 415 & 100,00 \\
\hline \multirow{4}{*}{ KR (Amirimin sergilediği tutum ve davranışlar, çalışanları motive edici yöndedir.) } & Katıliyorum & 405 & 54,80 \\
\hline & Kararsızım & 130 & 17,59 \\
\hline & Katılmiyorum & 204 & 27,60 \\
\hline & Toplam & 739 & 100,00 \\
\hline \multirow{4}{*}{$\begin{array}{l}\text { KR (Kurumumda görev, yetki ve sorumluluklar birimler arasında dengeli bir şekilde } \\
\text { paylaştırılmıştır.) }\end{array}$} & Katılıyorum & 319 & 43,17 \\
\hline & Kararsızım & 135 & 18,27 \\
\hline & Katılmıyorum & 285 & 38,57 \\
\hline & Toplam & 739 & 100,00 \\
\hline \multirow{4}{*}{ KR (Kurumumda personel, birimler arasında dengeli ve adil bir biçimde dağıtılmıştır.) } & Kat1liyorum & 333 & 45,06 \\
\hline & Kararsızım & 142 & 19,22 \\
\hline & Katılmiyorum & 264 & 35,72 \\
\hline & Toplam & 739 & 100,00 \\
\hline \multirow{4}{*}{$\begin{array}{l}\text { KR (Yönetim Kurulu çalışanların mesleklerinde gelişmeleri (hizmet içi eğitimlere katılımlarda, } \\
\text { yüksek lisans yapmada vs.) için gerekli desteği verir) }\end{array}$} & Katıliyorum & 385 & 52,10 \\
\hline & Kararsızım & 158 & 21,38 \\
\hline & Katılmıyorum & 196 & 26,52 \\
\hline & Toplam & 739 & 100,00 \\
\hline
\end{tabular}


AYDEMİ, Süleyman Ruhi - Türk Kamu Yönetiminde Ticaret Odaları ve Ticaret Borsaları Personeli Sorunu Araştırması

\begin{tabular}{|c|c|c|c|}
\hline \multirow{4}{*}{$\begin{array}{l}\text { KR (Yönetim Kurulu iyi performans gösteren personeli aylıkla veya takdir, teşekkür vs ile } \\
\text { ödüllendirir.) }\end{array}$} & Katıliyorum & 268 & 36,27 \\
\hline & Kararsızım & 121 & 16,37 \\
\hline & Katılmiyorum & 350 & 47,36 \\
\hline & Toplam & 739 & 100,00 \\
\hline \multirow{4}{*}{ KR (Kurumumda yaptığım iş için gerekli yetki, sorumluluk ve inisiyatif tanınmaktadır) } & Katıliyorum & 467 & 63,19 \\
\hline & Kararsızım & 121 & 16,37 \\
\hline & Katılmiyorum & 151 & 20,43 \\
\hline & Toplam & 739 & 100,00 \\
\hline \multirow{4}{*}{ KR (Kurumumda, çalışanların duygu ve değerlerine saygı gösterilmektedir.) } & Katıliyorum & 423 & 57,24 \\
\hline & Kararsızım & 124 & 16,78 \\
\hline & Katılmiyorum & 192 & 25,98 \\
\hline & Toplam & 739 & 100,00 \\
\hline \multirow{4}{*}{ KR (Yönetim Kurulu, işimi mevzuat çerçevesinde en iyi şekilde yapmam için beni serbest bırakır) } & Katıliyorum & 458 & 61,98 \\
\hline & Kararsızım & 139 & 18,81 \\
\hline & Katılmiyorum & 142 & 19,22 \\
\hline & Toplam & 739 & 100,00 \\
\hline \multirow{4}{*}{$\begin{array}{l}\text { KR (Amirim, işimi mevzuat talimatlar çerçevesinde en iyi şekilde yapmam için beni serbest } \\
\text { bırakır) }\end{array}$} & Katılıyorum & 525 & 71,04 \\
\hline & Kararsızım & 99 & 13,40 \\
\hline & Katılmiyorum & 115 & 15,56 \\
\hline & Toplam & 739 & 100,00 \\
\hline \multirow{4}{*}{ KR (Sorun çıktığında, birbirimizi suçlamak yerine çözümü araştırmayı tercih ederiz) } & Katıliyorum & 461 & 62,38 \\
\hline & Kararsızım & 123 & 16,64 \\
\hline & Katılmiyorum & 155 & 20,97 \\
\hline & Toplam & 739 & 100,00 \\
\hline \multirow{4}{*}{ KR (Yönetim Kurulundan işimle ilgili görevden uzaklaştırma şeklinde tehdit almaktayım.) } & Katıliyorum & 121 & 16,37 \\
\hline & Kararsizim & 65 & 8,80 \\
\hline & Katılmiyorum & 553 & 74,83 \\
\hline & Toplam & 739 & 100,00 \\
\hline \multirow{4}{*}{$\begin{array}{l}\text { KR (Yönetim Kurulundan dolaylı veya dolaysız olarak işime son verilme şeklinde tehdit } \\
\text { almaktayım.) }\end{array}$} & Katıliyorum & 119 & 16,10 \\
\hline & Kararsızım & 63 & 8,53 \\
\hline & Katılmiyorum & 557 & 75,37 \\
\hline & Toplam & 739 & 100,00 \\
\hline \multirow{4}{*}{ KR (Başarılarım iş arkadaşlarım tarafından takdir edilmektedir.) } & Katıliyorum & 431 & 58,32 \\
\hline & Kararsızım & 156 & 21,11 \\
\hline & Katılmiyorum & 152 & 20,57 \\
\hline & Toplam & 739 & 100,00 \\
\hline
\end{tabular}




\begin{tabular}{|c|c|c|c|}
\hline \multirow{4}{*}{ İS (Kurumumun ne iş yaptığını bilerek burda çalışmaya başladım) } & Katıliyorum & 579 & 78,35 \\
\hline & Kararsızım & 53 & 7,17 \\
\hline & Katılmiyorum & 107 & 14,48 \\
\hline & Toplam & 739 & 100,00 \\
\hline \multirow{4}{*}{ İS (Kuruma personel alınacağı zaman fikrim alınmaktadır.) } & Kat1liyorum & 197 & 26,66 \\
\hline & Kararsızım & 66 & 8,93 \\
\hline & Katılmiyorum & 476 & 64,41 \\
\hline & Toplam & 739 & 100,00 \\
\hline \multirow{4}{*}{ İS (İşimi kaybetme endişesi taşımaktayım.) } & Kat1liyorum & 305 & 41,27 \\
\hline & Kararsızım & 115 & 15,56 \\
\hline & Katılmiyorum & 319 & 43,17 \\
\hline & Toplam & 739 & 100,00 \\
\hline \multirow{4}{*}{$\begin{array}{l}\text { İS (Kuruma yeni alınacak personel için istihdamın nasıl sağlanacağına dair bir yöntem veya metod } \\
\text { mevcuttur. Bunun dışında istihdam sağlanmaz) }\end{array}$} & Kat1liyorum & 320 & 43,30 \\
\hline & Kararsızım & 165 & 22,33 \\
\hline & Katılmiyorum & 254 & 34,37 \\
\hline & Toplam & 739 & 100,00 \\
\hline \multirow{4}{*}{ İS (Bu Kurumumun bir çalışanı olmaktan memnunum.) } & Kat1liyorum & 584 & 79,03 \\
\hline & Kararsızım & 81 & 10,96 \\
\hline & Katılmıyorum & 74 & 10,01 \\
\hline & Toplam & 739 & 100,00 \\
\hline \multirow{4}{*}{ İS (Yaptığım işten zevk alıyorum ve işimi seviyorum.) } & Katıliyorum & 616 & 83,36 \\
\hline & Kararsizım & 67 & 9,07 \\
\hline & Katılmıyorum & 56 & 7,58 \\
\hline & Toplam & 739 & 100,00 \\
\hline \multirow{4}{*}{ İS (Bilgi ve yeteneklerime uygun bir iş yapmaktayım.) } & Kat1liyorum & 590 & 79,84 \\
\hline & Kararsızım & 88 & 11,91 \\
\hline & Katılmıyorum & 61 & 8,25 \\
\hline & Toplam & 739 & 100,00 \\
\hline \multirow{4}{*}{ İS (Kurumumda personelin problemleri süratle çözümlenmektedir.) } & Kat1liyorum & 339 & 45,87 \\
\hline & Kararsızım & 170 & 23,00 \\
\hline & Katılmiyorum & 230 & 31,12 \\
\hline & Toplam & 739 & 100,00 \\
\hline \multirow{4}{*}{ İS (Yönetim Kuruluna sorunlarımı iletme imkânı bulurum) } & Katıliyorum & 386 & 52,23 \\
\hline & Kararsızım & 128 & 17,32 \\
\hline & Katılmıyorum & 225 & 30,45 \\
\hline & Toplam & 739 & 100,00 \\
\hline
\end{tabular}


AYDEMİ, Süleyman Ruhi - Türk Kamu Yönetiminde Ticaret Odaları ve Ticaret Borsaları Personeli Sorunu Araştırması

\begin{tabular}{|c|c|c|c|}
\hline \multirow{4}{*}{ İS (Amirime sorunlarımı iletme imkânı bulurum) } & Katıliyorum & 566 & 76,59 \\
\hline & Kararsızım & 80 & 10,83 \\
\hline & Katılmiyorum & 93 & 12,58 \\
\hline & Toplam & 739 & 100,00 \\
\hline \multirow{4}{*}{ İS (İse başladığımda hizmet içi eğitimden geçtim) } & Katıliyorum & 396 & 53,59 \\
\hline & Kararsızım & 56 & 7,58 \\
\hline & Katılmiyorum & 287 & 38,84 \\
\hline & Toplam & 739 & 100,00 \\
\hline \multirow{4}{*}{ İS (Kuruma personel alınırken KPSS puanı şart olmalıdır) } & Katıliyorum & 331 & 44,79 \\
\hline & Kararsızım & 153 & 20,70 \\
\hline & Katılmiyorum & 255 & 34,51 \\
\hline & Toplam & 739 & 100,00 \\
\hline \multirow{4}{*}{ İS (Aldığım eğitime uygun bir bölümde çalışıyorum.) } & Katıliyorum & 534 & 72,26 \\
\hline & Kararsızım & 83 & 11,23 \\
\hline & Katılmiyorum & 122 & 16,51 \\
\hline & Toplam & 739 & 100,00 \\
\hline \multirow{4}{*}{$\begin{array}{l}\text { İS (Çalışma ortamım ve çalışma koşullarım ile ilgili yapılacak düzenlemelerde görüşüme } \\
\text { başvurulur.) }\end{array}$} & Katıliyorum & 410 & 55,48 \\
\hline & Kararsizım & 110 & 14,88 \\
\hline & Katılmiyorum & 219 & 29,63 \\
\hline & Toplam & 739 & 100,00 \\
\hline \multirow{4}{*}{ İS (Çalıştığım bölümün işleyişi konusunda önerilerim dikkate alınır.) } & Katıliyorum & 510 & 69,01 \\
\hline & Kararsızım & 79 & 10,69 \\
\hline & Katılmiyorum & 150 & 20,30 \\
\hline & Toplam & 739 & 100,00 \\
\hline \multirow{4}{*}{ İS (Kurumum kariyer planlarımı gerçekleştirmemde bana olanaklar sunmaktadır.) } & Katıliyorum & 329 & 44,52 \\
\hline & Kararsızım & 178 & 24,09 \\
\hline & Katılmiyorum & 232 & 31,39 \\
\hline & Toplam & 739 & 100,00 \\
\hline \multirow{4}{*}{ İS (Çalıştığım kurumdan ayrılmayı hiç düşünmem) } & Katıliyorum & 442 & 59,81 \\
\hline & Kararsızım & 150 & 20,30 \\
\hline & Katılmiyorum & 147 & 19,89 \\
\hline & Toplam & 739 & 100,00 \\
\hline \multirow{4}{*}{ İS (İşe alınmamda Yönetim Kurulunun katkısı olmuştur.) } & Katıliyorum & 425 & 57,51 \\
\hline & Kararsızım & 100 & 13,53 \\
\hline & Katılmiyorum & 214 & 28,96 \\
\hline & Toplam & 739 & 100,00 \\
\hline
\end{tabular}




\begin{tabular}{|c|c|c|c|}
\hline \multirow{4}{*}{ İS (Kuruma personel alınırken Yönetim Kurulu yakını olmak öncelik tercih sebebidir) } & Katıliyorum & 313 & 42,35 \\
\hline & Kararsızım & 117 & 15,83 \\
\hline & Katılmiyorum & 309 & 41,81 \\
\hline & Toplam & 739 & 100,00 \\
\hline \multirow{4}{*}{ İS (Çalışabileceğim en iyi kuruluşun yine de burası olduğunu düşünüyorum) } & Kat1liyorum & 453 & 61,30 \\
\hline & Kararsızım & 168 & 22,73 \\
\hline & Katılmiyorum & 118 & 15,97 \\
\hline & Toplam & 739 & 100,00 \\
\hline \multirow{4}{*}{ İS (Son 1 y1l içerisinde istifa etmeyi düşündüm.) } & Kat1liyorum & 220 & 29,77 \\
\hline & Kararsızım & 89 & 12,04 \\
\hline & Katılmiyorum & 430 & 58,19 \\
\hline & Toplam & 739 & 100,00 \\
\hline \multirow{4}{*}{ İS (Sebepsiz yere işten çıkarılan arkadaşımız bulunmaktadır.) } & Kat1liyorum & 131 & 17,73 \\
\hline & Kararsızım & 80 & 10,83 \\
\hline & Katılmiyorum & 528 & 71,45 \\
\hline & Toplam & 739 & 100,00 \\
\hline \multirow{4}{*}{ İS (Yönetim değiş̧ikleri beni tedirgin eder) } & Kat1liyorum & 391 & 52,91 \\
\hline & Kararsızım & 118 & 15,97 \\
\hline & Katılmiyorum & 230 & 31,12 \\
\hline & Toplam & 739 & 100,00 \\
\hline \multirow{4}{*}{ İS (Çalışma yaşamımda mobbingle karşı karşıya kalmaktayım) } & Katıliyorum & 213 & 28,82 \\
\hline & Kararsizım & 159 & 21,52 \\
\hline & Katılmiyorum & 367 & 49,66 \\
\hline & Toplam & 739 & 100,00 \\
\hline \multirow{4}{*}{ ÖZ (Haklarım, ödev ve sorumluluklarımla ilgili mevzuatı biliyorum.) } & Kat1liyorum & 663 & 89,72 \\
\hline & Kararsızım & 39 & 5,28 \\
\hline & Katılmıyorum & 37 & 5,01 \\
\hline & Toplam & 739 & 100,00 \\
\hline \multirow{4}{*}{ ÖZ (Geçim sıkıntısı çekiyorum.) } & Katıliyorum & 417 & 56,43 \\
\hline & Kararsızım & 89 & 12,04 \\
\hline & Katılmiyorum & 233 & 31,53 \\
\hline & Toplam & 739 & 100,00 \\
\hline \multirow{4}{*}{ ÖZ (Personel arasındaki maaş aralıkları dikkat çekici düzeydedir) } & Katıliyorum & 441 & 59,68 \\
\hline & Kararsızım & 100 & 13,53 \\
\hline & Katılmıyorum & 198 & 26,79 \\
\hline & Toplam & 739 & 100,00 \\
\hline
\end{tabular}


AYDEMİ, Süleyman Ruhi - Türk Kamu Yönetiminde Ticaret Odaları ve Ticaret Borsaları Personeli Sorunu Araştırması

\begin{tabular}{|c|c|c|c|}
\hline \multirow{4}{*}{ ÖZ (Personele verilen maaşlar yetki, görev ve sorumluluk dikkate alınarak belirlenmektedir) } & Katıliyorum & 327 & 44,25 \\
\hline & Kararsızım & 118 & 15,97 \\
\hline & Katılmiyorum & 294 & 39,78 \\
\hline & Toplam & 739 & 100,00 \\
\hline \multirow{4}{*}{ ÖZ (Başka Oda/Borsalarda benimle aynı işi yapan daha fazla özlük haklarına sahiptir.) } & Katıliyorum & 451 & 61,03 \\
\hline & Kararsızım & 189 & 25,58 \\
\hline & Katılmiyorum & 99 & 13,40 \\
\hline & Toplam & 739 & 100,00 \\
\hline \multirow{4}{*}{ ÖZ (Yıllık izinlerimi istediğim zaman kullanabiliyorum.) } & Katıliyorum & 525 & 71,04 \\
\hline & Kararsızım & 62 & 8,39 \\
\hline & Katılmiyorum & 152 & 20,57 \\
\hline & Toplam & 739 & 100,00 \\
\hline \multirow{4}{*}{ ÖZ (Y1llık izinlerimi tam olarak kullanabiliyorum.) } & Katıliyorum & 522 & 70,64 \\
\hline & Kararsızım & 43 & 5,82 \\
\hline & Katılmiyorum & 174 & 23,55 \\
\hline & Toplam & 739 & 100,00 \\
\hline \multirow{4}{*}{ ÖZ (Mazeret İzinlerimi istediğim zaman kullanabiliyorum.) } & Katıliyorum & 546 & 73,88 \\
\hline & Kararsızım & 59 & 7,98 \\
\hline & Katılmiyorum & 134 & 18,13 \\
\hline & Toplam & 739 & 100,00 \\
\hline \multirow{4}{*}{ ÖZ (Mesaiden tam zamanında çıkamıyorum) } & Katıliyorum & 330 & 44,65 \\
\hline & Kararsızım & 70 & 9,47 \\
\hline & Katılmiyorum & 339 & 45,87 \\
\hline & Toplam & 739 & 100,00 \\
\hline \multirow{4}{*}{ ÖZ (İkramiyelerimi, fazla mesai ücretlerimi zamanında ve eksiksiz alıyorum.) } & Katıliyorum & 415 & 56,16 \\
\hline & Kararsızım & 59 & 7,98 \\
\hline & Katılmiyorum & 265 & 35,86 \\
\hline & Toplam & 739 & 100,00 \\
\hline \multirow{4}{*}{ ÖZ (Hastalandığımda hastaneye gidip tedavide problem yaşıyorum) } & Katıliyorum & 384 & 51,96 \\
\hline & Kararsızım & 43 & 5,82 \\
\hline & Katılmiyorum & 312 & 42,22 \\
\hline & Toplam & 739 & 100,00 \\
\hline \multirow{4}{*}{ ÖZ (Şehir dışında hastalandığımda hastaneye gidip tedavide problem yaşıyorum) } & Katıliyorum & 449 & 60,76 \\
\hline & Kararsızım & 102 & 13,80 \\
\hline & Katılmiyorum & 188 & 25,44 \\
\hline & Toplam & 739 & 100,00 \\
\hline
\end{tabular}




\begin{tabular}{|c|c|c|c|}
\hline \multirow{4}{*}{ ÖZ (Hastalık raporu aldığımda buna ilişkin iznimi rahatlıkla kullanabiliyorum.) } & Katıliyorum & 510 & 69,01 \\
\hline & Kararsızım & 106 & 14,34 \\
\hline & Katılmiyorum & 123 & 16,64 \\
\hline & Toplam & 739 & 100,00 \\
\hline \multirow{4}{*}{ ÖZ (Kurumumda yapılan atama ve terfilerde liyakate dikkat edilmektedir.) } & Kat1liyorum & 343 & 46,41 \\
\hline & Kararsızım & 175 & 23,68 \\
\hline & Katılmiyorum & 221 & 29,91 \\
\hline & Toplam & 739 & 100,00 \\
\hline \multirow{4}{*}{$\begin{array}{l}\text { ÖZ (Yönetim tarafindan çalışanları ödüllendirme (teşekkür yazıları, ek ödeme ilave puanı, vb.) } \\
\text { mekanizmaları işletilmektedir.) }\end{array}$} & Kat1liyorum & 247 & 33,42 \\
\hline & Kararsızım & 124 & 16,78 \\
\hline & Katılmiyorum & 368 & 49,80 \\
\hline & Toplam & 739 & 100,00 \\
\hline \multirow{4}{*}{ ÖZ (Yazılı ve sözlü cezalandırmalarda personel arasında ayrım yapılmaktadır.) } & Katıliyorum & 240 & 32,48 \\
\hline & Kararsızım & 148 & 20,03 \\
\hline & Katılmiyorum & 351 & 47,50 \\
\hline & Toplam & 739 & 100,00 \\
\hline \multirow{4}{*}{ ÖZ (Disiplin uygulamaları dökümanlarla açık ve net olarak bildirilmiştir.) } & Kat1lyorum & 422 & 57,10 \\
\hline & Kararsızım & 171 & 23,14 \\
\hline & Katılmiyorum & 146 & 19,76 \\
\hline & Toplam & 739 & 100,00 \\
\hline \multirow{4}{*}{$\begin{array}{l}\text { ÖZ (Her türlü ödüllendirme ve terfilerde bireysel performans değerlendirme sonuçları esas } \\
\text { alınmaktadır.) }\end{array}$} & Katılıyorum & 272 & 36,81 \\
\hline & Kararsızım & 157 & 21,24 \\
\hline & Katılmiyorum & 310 & 41,95 \\
\hline & Toplam & 739 & 100,00 \\
\hline \multirow{4}{*}{ ÖZ (En küçük hatamda bile sözlü ve yazılı uyarıyla karşılaşıyorum) } & Katıliyorum & 207 & 28,01 \\
\hline & Kararsızım & 107 & 14,48 \\
\hline & Katılmiyorum & 425 & 57,51 \\
\hline & Toplam & 739 & 100,00 \\
\hline \multirow{4}{*}{ ÖZ (Yönetim Kurulu kurumdan ayrılmadan işyerinden ayrılamıyorum) } & Kat1liyorum & 281 & 38,02 \\
\hline & Kararsızım & 68 & 9,20 \\
\hline & Katılmiyorum & 390 & 52,77 \\
\hline & Toplam & 739 & 100,00 \\
\hline \multirow{4}{*}{ ÖZ (Bir sendikaya üye olma hakkımın olduğunu biliyorum) } & Kat1liyorum & 192 & 25,98 \\
\hline & Kararsızım & 158 & 21,38 \\
\hline & Katılmıyorum & 389 & 52,64 \\
\hline & Toplam & 739 & 100,00 \\
\hline
\end{tabular}


AYDEMİ, Süleyman Ruhi - Türk Kamu Yönetiminde Ticaret Odaları ve Ticaret Borsaları Personeli Sorunu Araştırması

\begin{tabular}{|c|c|c|c|}
\hline \multirow{4}{*}{ ÖZ (Bir Sendikaya üyeyim) } & Katıliyorum & 12 & 1,62 \\
\hline & Kararsızım & 26 & 3,52 \\
\hline & Katılmiyorum & 701 & 94,86 \\
\hline & Toplam & 739 & 100,00 \\
\hline \multirow{4}{*}{ ÖZ (Faydasına inanmadığım için sendikaya üye olmadım) } & Katıliyorum & 180 & 24,36 \\
\hline & Kararsızım & 190 & 25,71 \\
\hline & Katılmiyorum & 369 & 49,93 \\
\hline & Toplam & 739 & 100,00 \\
\hline \multirow{4}{*}{ ÖZ (Sendikaya üye olursam işimle ilgili sıkıntı yaşarım.) } & Katıliyorum & 239 & 32,34 \\
\hline & Kararsızım & 223 & 30,18 \\
\hline & Katılmiyorum & 277 & 37,48 \\
\hline & Toplam & 739 & 100,00 \\
\hline \multirow{4}{*}{ ÖZ (Başka bir Odaya/Borsaya tayin hakkımın olmasını isterdim) } & Katıliyorum & 559 & 75,64 \\
\hline & Kararsızım & 77 & 10,42 \\
\hline & Katılmiyorum & 103 & 13,94 \\
\hline & Toplam & 739 & 100,00 \\
\hline \multirow{4}{*}{ ÖZ (5590 Sayılı Kanuna tabi olmaktan memnunum/tabi olmayı isterdim) } & Katılıyorum & 397 & 61,84 \\
\hline & Kararsızım & 144 & 22,43 \\
\hline & Katılmiyorum & 101 & 15,73 \\
\hline & Toplam & 642 & 100,00 \\
\hline \multirow{4}{*}{ ÖZ (5174 sayılı Kanuna tabi olmaktan memnunum/tabi olmayı isterdim) } & Katıliyorum & 217 & 29,36 \\
\hline & Kararsızım & 175 & 23,68 \\
\hline & Katılmiyorum & 347 & 46,96 \\
\hline & Toplam & 739 & 100,00 \\
\hline \multirow{4}{*}{ ÖZ (Devlette Kamu çalışanı statüsüne alınmak isterdim) } & Katılıyorum & 659 & 89,17 \\
\hline & Kararsızım & 48 & 6,50 \\
\hline & Katılmiyorum & 32 & 4,33 \\
\hline & Toplam & 739 & 100,00 \\
\hline
\end{tabular}

\subsubsection{Araștırma Sonucunda Elde Edilen Bulgular'}

\subsubsection{Kurumsallaşma ve İç İşleyişe Yönelik Elde Edilen Bulgular}

"Kurumsallaşma ve iç işleyiş"e yönelik toplam 56 adet hipotez kurulmuştur. Kurulan hipotezler ve bunlara

9 Bu bölüm altında yer alan tablolardaki 'Yorum' sütunlarında yer alan harflerin açıklamaları şu şekildedir;

a- Hipotez tam olarak kabul edilmiştir. Hipotez bağımsız değişkenler bağlamında anlamlı fark kesinlikle göstermemektedir.

b- Hipotez kabul edilmiştir. Hipotez bağımsız değişkenler bağlamında anlamlı fark kesinlikle göstermemekle birlikte Khi-kare Significiant değeri kritik noktadır. Veri sayısı artarsa anlamlı fark olma ihtimali bulunmaktadır.

c- Hipotez reddedilmiştir. Bağımsız değişkenler çerçevesinde anlamlı fark vardır. Khi-kare Significiant değeri \%4-\%1 arasındadır. Veri sayısı arttığında fark kapanma ihtimali bulunmaktadır.

d- Hipotez güçlü bir şekilde reddedilmiştir. Bağımsız değişkenler bağlamında anlamlı fark vardır. Khi-kare Significiant değeri \%1-\%0,1 arasındadır.

e- Hipotez çok güçlü bir şekilde reddedilmiştir. Anlamlı fark vardır ve keskindir. Khi-kare Significiant değeri \%0,1' den küçüktür. 
yönelik uygulanan çapraz test ile khi-kare sonuçları aşağıdaki gibidir.

Tablo 6. Kurumsallaşma Ve İç İşleyişe Yönelik Kurulan Hipotezlere Uygulanan Çapraz Test İle Khi-Kare Sonuçları

\begin{tabular}{|c|c|c|c|c|}
\hline Hipotez Açıklaması & $\begin{array}{l}\text { Bağımsız } \\
\text { Değişkenler }\end{array}$ & $\begin{array}{l}\text { Khi Kare } \\
\text { Significiant } \\
\text { Değeri }\end{array}$ & Sonuç & Yorum \\
\hline \multirow{8}{*}{$\begin{array}{l}\text { Yönetim Kurulunun, Kurumu Kendi İşyerleri Gibi Yönettiği Düşüncesinin } \\
\text { Bağımsız Değişkenlere Göre Anlamlı Farklılık Gösterip Göstermediği. }\end{array}$} & Cinsiyet & 0,076 & Kabul & b \\
\hline & Eğitim & 0,263 & Kabul & $\mathbf{a}$ \\
\hline & Kurum & 0,869 & Kabul & $\mathbf{a}$ \\
\hline & Bölge & 0,474 & Kabul & $\mathbf{a}$ \\
\hline & Yerleşim Yeri & 0,539 & Kabul & $\mathbf{a}$ \\
\hline & Statü & 0,054 & Kabul & b \\
\hline & Maaş & 0,00 & Ret & $\mathrm{e}$ \\
\hline & Pozisyon & 0,777 & Kabul & $\mathbf{a}$ \\
\hline \multirow{8}{*}{$\begin{array}{l}\text { Personelin İşiyle İlgili Sorunlarını Yönetim Kurulu İle Paylaşıp Paylaşmamasının } \\
\text { Bağımsız Değişkenlere Göre Anlamlı Farklılık Gösterip Göstermediği. }\end{array}$} & Cinsiyet & 0,129 & Kabul & b \\
\hline & Eğitim & 0,01 & Ret & $\mathrm{d}$ \\
\hline & Kurum & 0,280 & Kabul & $\mathbf{a}$ \\
\hline & Bölge & 0,30 & Kabul & $\mathbf{a}$ \\
\hline & Yerleşim Yeri & 0,00 & Ret & $\mathrm{e}$ \\
\hline & Statü & 0,04 & Ret & $\mathrm{d}$ \\
\hline & Maaș & 0,06 & Ret & $\mathrm{d}$ \\
\hline & Pozisyon & 0,00 & Ret & $\mathrm{e}$ \\
\hline \multirow{8}{*}{$\begin{array}{l}\text { Personelin İşiyle İlgili En Küçük Aksaklıkta, Yönetim Kurulu Tarafından } \\
\text { Kendisine Olumsuz Tavır Alınıp Alınmadığının, Bağımsız Değişkenlere Göre } \\
\text { Anlamlı Farklılık Gösterip Göstermediği. }\end{array}$} & Cinsiyet & 0,539 & Kabul & $\mathbf{a}$ \\
\hline & Ĕ̆itim & 0,337 & Kabul & $\mathbf{a}$ \\
\hline & Kurum & 0,00 & Ret & $\mathrm{e}$ \\
\hline & Bölge & 0,61 & Kabul & $\mathbf{a}$ \\
\hline & Yerlesim Yeri & 0,430 & Kabul & $\mathbf{a}$ \\
\hline & Statü & 0,750 & Kabul & $\mathbf{a}$ \\
\hline & Maaş & 0,379 & Kabul & $\mathbf{a}$ \\
\hline & Pozisyon & 0,098 & Kabul & $\mathbf{a}$ \\
\hline \multirow{8}{*}{$\begin{array}{l}\text { Çalışanlarla İlgili Kararların, Çalışanların Katılımıyla Demokratik Bir Şekilde } \\
\text { Alınmadığı Düşüncesinin Bağımsız Değişkenlere Göre Anlamlı Farklılık } \\
\text { Gösterip Göstermediği }\end{array}$} & Cinsiyet & 0,825 & Kabul & $\mathbf{a}$ \\
\hline & Eğitim & 0,030 & Ret & $\mathrm{c}$ \\
\hline & Kurum & 0,060 & Ret & $\mathrm{c}$ \\
\hline & Bölge & 0,362 & Kabul & $\mathbf{a}$ \\
\hline & Yerleşim Yeri & 0,128 & Kabul & $\mathbf{a}$ \\
\hline & Statü & 0,026 & Ret & d \\
\hline & Maaş & 0,013 & Ret & $\mathrm{d}$ \\
\hline & Pozisyon & 0,000 & Ret & $\mathrm{e}$ \\
\hline \multirow{8}{*}{$\begin{array}{l}\text { Kurumda Görev, Yetki Ve Sorumlulukların Birimler Arasında Dengeli Bir } \\
\text { Şekilde Paylaştııılmadığı Düşüncesinin Bağımsız Değişkenlere Göre Anlamlı } \\
\text { Farklılık Gösterip Göstermediği }\end{array}$} & Cinsiyet & 0,060 & Kabul & $\mathbf{b}$ \\
\hline & Eğitim & 0,047 & Ret & $\mathrm{c}$ \\
\hline & Kurum & 0,558 & Kabul & $\mathbf{a}$ \\
\hline & Bölge & 0,188 & Kabul & $\mathbf{a}$ \\
\hline & Yerleşim Yeri & 0,142 & Kabul & $\mathbf{a}$ \\
\hline & Statü & 0,08 & Ret & $\mathrm{d}$ \\
\hline & Maaş & 0,000 & Ret & $\mathrm{e}$ \\
\hline & Pozisyon & 0,000 & Ret & $\mathrm{e}$ \\
\hline \multirow{8}{*}{$\begin{array}{l}\text { Personelin, Birimler Arasında Dengeli ve Adil Bir Biçimde Dağıtılmadığı } \\
\text { Düşüncesinin } \\
\text { Göstermediğg }\end{array}$} & Cinsiyet & 0,051 & Kabul & b \\
\hline & Eğitim & 0,725 & Kabul & $\mathbf{a}$ \\
\hline & Kurum & 0,797 & Kabul & $\mathbf{a}$ \\
\hline & Bölge & 0,11 & Kabul & $\mathbf{c}$ \\
\hline & Yerleşim Yeri & 0,158 & Kabul & $\mathbf{e}$ \\
\hline & Statü & 0,216 & Kabul & d \\
\hline & Maaş & 0,08 & Kabul & d \\
\hline & Pozisyon & 0,000 & Ret & $\mathrm{e}$ \\
\hline \multirow{8}{*}{$\begin{array}{l}\text { İyi Performans Gösteren Personelin Ödüllendirilmediği Düşüncesinin Bağımsız } \\
\text { Değişkenlere Göre Anlamlı Farklıllk Gösterip Göstermediği }\end{array}$} & Cinsiyet & 0,420 & Kabul & $\mathbf{a}$ \\
\hline & Eğitim & 0,20 & Kabul & $\mathbf{c}$ \\
\hline & Kurum & 0,000 & Ret & $\mathrm{e}$ \\
\hline & Bölge & 0,053 & Kabul & b \\
\hline & Yerleşim Yeri & 0,764 & Kabul & $\mathbf{a}$ \\
\hline & Statü & 0,018 & Ret & $\mathrm{c}$ \\
\hline & Maaș & 0,017 & Ret & $\mathrm{c}$ \\
\hline & Pozisyon & 0,03 & Ret & $\mathrm{d}$ \\
\hline
\end{tabular}

Kurumsallaşma ve iç işleyişe yönelik kurulan hipotezler ve yapılan khi kare test sonuçlarına göre, odalar ve borsalarda çalışan personel yönetim kurulunun, kurumu kendi işyerleri gibi yönettiği düşüncesine hakimdir ve bu düşünce cinsiyet, eğitim, çalışılan kurum, bölge, yerleşim yeri, işe girme tarihi (statü), bağımsız değişkenlerine göre anlamlı olarak farklılık göstermemektedir. Sadece alınan ortalama maaş açısından anlamlı farklılık vardır ve bu farklılığın sebebi maaşların 1600 TL den başlama üzere 4500 TL' yi geçecek biçimde 
dengesiz bir biçimde olması ve bunun ise personelin yönetim kuruluna bakış açısına yansımasından kaynaklanmaktadır.

Personelin işiyle ilgili sorunlarını yönetim kurulu ile paylaşıp paylaşamaması cinsiyet, bölge ve çalışılan kurum bağımsız değişkenlerine göre anlamlı farklılık göstermemekte, ancak, eğitim, statü, maaş, pozisyon bağımsız değişkenlerine göre anlamlı bir farklılık ortaya çıkmaktadır. Eğitim seviyesi yükseldikçe çalışanların sorunlarını yönetimle paylaşamadığı fikri artmaktadır. 5174 sayılı kanuna tabi personel sorunlarını yönetim kurulu ile paylaşma noktasında daha çekingenlik içindedir. Personelin maaşları arttıkça yönetim kurulu ile olan ilişkilerinin daha sık olduğu ve sorunlarını paylaştığı anlaşılmaktadır. Benzer durum pozisyonla da alakalıdır. Amir konumundaki personel yönetim kurulu ile daha çok mesai harcadıkları için bu soruya "katılıyorum" cevabı verme oranları daha yüksektir.

Personelin işiyle ilgili en küçük aksaklıkta, yönetim kurulu tarafından kendisine olumsuz tavır alınıp alınmadığı, bağımsız değişkenlerden "çalışılan kurum” hariç olmak üzere diğerlerinde anlamlı fark bulunmamaktadır. Genel olarak, en küçük aksaklıkta yönetim kurulunun kendisine olumsuz tavır alındığı düşüncesi oran1 \%33'tür. Kurum bazlı anlamlı fark çıkmasının sebebi bu oranın Deniz Ticaret Odasında \%6,25'e inmesidir.

Çalışanlarla ilgili kararların çalışanların katılımıyla demokratik bir şekilde alınmadığı düşüncesi bağımsız değişkenlerden cinsiyet, bölge ve yerleşim yerine göre anlamlı fark göstermemekte, diğer bağımsız değişkenlere göre anlamlı fark ortaya çıkmaktadır. Genel olarak \%41,14'lük şeklinde "katılmıyorum" cevabı eğitim düzeyi yükseldikçe artmaktadır. Kurum bazında anlamlı fark çıkmasının sebebi sanayi odalarındaki oranın \%25 olmasından kaynaklanmaktadır. Statü bağlamında anlamlı fark çıkmasının sebebi taşeron personelin katılmama oranının oldukça yüksek olmasından kaynaklanmaktadır. Katılmama oranı maaş miktarı ile ters orantılıdır. Maaş miktarı yükseldikçe katılmama oranı düşmektedir. Amir konumundakilere göre çalışanlarla ilgili kararlar çalışanların katılımıyla demokratik bir şekilde alınırken genel sekreter dışındaki personele göre bu, tam tersidir.

Odalar ve borsalarda çalışan personel, kurumda görev, yetki ve sorumlulukların birimler arasında dengeli bir şekilde paylaştırılmadığı düşüncesine sahiptir ve bu; eğitim, statü, aylık maaş ve pozisyona göre anlamlı fark çıkmakta, diğer bağımsız değişkenlere göre istatistiki olarak anlamlı bir fark ortaya çıkmamaktadır. Genel olarak \%38,57'lik oranda kurumda görev, yetki ve sorumlulukların birimler arasında dengeli bir şekilde paylaştırılmadığı düşüncesi vardır. Eğitim düzeyi bağlamında dengeli bir dağılım bulunmaktadır ve khi kare test sonucu kritik eşiktedir. 5174 sayılı Kanuna tabi personelin katılmama oran1 5590 say1lı Kanuna tabi personele göre yüksektir. Düşük maaş alan personelin katılmama oranı yüksek maaş alanlara göre oldukça yüksektir. Ayrıca, genel sekreterlerin katılmama oranı diğer personellere göre oldukça düşüktür.

Anket sonuçlarına göre, personelin birimler arasında dengeli ve adil bir biçimde dağıtılmadığı düşüncesi hakimdir ve bu düşünce bağımsız değişkenlerden pozisyon hariç diğerlerine göre anlamlı fark göstermemektedir. Bunun sebebi, pozisyonlar içinde yer alan anket katılımcıları arasında amir konumunda olan kurum genel sekreterlerinin olması olarak gösterilebilir. Ortalama olarak \%35,72'lik katılmama oranı genel sekreterlerde \%14,68'e düşmektedir.

İyi performans gösteren personelin ödüllendirilmediği düşüncesi; cinsiyet, eğitim, bölge ve yerleşim yeri bağımsız değişkenlerine göre anlamlı fark göstermemekte iken, kurum, statü, maaş ve pozisyon bağımsız değişenlerine göre anlamlı farklar ortaya çıkmaktadır. Kurum bazında anlamlı fark çıkmasının sebebi genel oran olan \%47,36'lık oranın sanayi odalarında \%33,33' e düşmesidir. 5174 sayılı Kanuna tabi personelin yarısı iyi performansın ödüllendirmediğini düşünürken bu oran 5590 sayılı Kanuna tabi personelde \%38,89'a düşmektedir. Maaşları yüksek olan personel, kurumdaki personelin performansa bağlı olarak ödüllendirildiğini düşünmektedir. Benzer şekilde genel sekterlerin \%50,46’ s1 da aynı düşünceye sahiptir. Bütün bunlar ise istatistiki olarak anlamlı farkları oluşturmaktadır.

\subsubsection{2. İstihdama Yönelik Elde Edilen Bulgular}

İstihdam sorunlarına yönelik toplam 48 adet hipotez kurulmuştur. Kurulan hipotezler ve bunlara yönelik uygulanan çapraz test ile khi kare sonuçları aşağıdaki gibidir. 
Tablo 7.İstihdama Yönelik Kurulan Hipotezlere Yönelik Uygulanan Çapraz Test İle Khi-Kare Sonuçları

\begin{tabular}{|c|c|c|c|c|}
\hline Hipotez Açıklaması & Bağımsız değişkenler & $\begin{array}{c}\text { Khi Kare } \\
\text { significiant } \\
\text { değeri }\end{array}$ & Sonuç & Yorum \\
\hline \multirow{8}{*}{$\begin{array}{l}\text { İşi Kaybetme Endişesinin Bağımsız Değişkenlere Göre } \\
\text { Anlamlı Farklılık Gösterip Göstermediği. }\end{array}$} & Cinsiyet & 0,06 & Ret & $\mathrm{d}$ \\
\hline & Eğitim & 0,301 & Kabul & $\mathbf{a}$ \\
\hline & Kurum & 0,10 & Ret & $\mathrm{c}$ \\
\hline & Bölge & 0,21 & Ret & $\mathrm{c}$ \\
\hline & Yerleşim Yeri & 0,305 & Kabul & $\mathbf{a}$ \\
\hline & Statü & 0,000 & Ret & $\mathrm{e}$ \\
\hline & Maaş & 0,000 & Ret & $\mathrm{e}$ \\
\hline & Pozisyon & 0,428 & Kabul & $\mathbf{a}$ \\
\hline \multirow{8}{*}{$\begin{array}{l}\text { Kurumda Çalışmaya Başladığında Hizmet İçi Eğitim } \\
\text { Alınmasının Bağımsız Değişkenlere Göre Anlamlı } \\
\text { Farklılık Gösterip Göstermediği. }\end{array}$} & Cinsiyet & 0,246 & Kabul & $\mathbf{a}$ \\
\hline & Eğitim & 0,370 & Kabul & $\mathbf{a}$ \\
\hline & Kurum & 0,154 & Kabul & $\mathbf{a}$ \\
\hline & Bölge & 0,699 & Kabul & $\mathbf{a}$ \\
\hline & Yerleşim Yeri & 0,237 & Kabul & $\mathbf{a}$ \\
\hline & Statü & 0,198 & Kabul & $\mathbf{a}$ \\
\hline & Maaş & 0,151 & Kabul & $\mathbf{a}$ \\
\hline & Pozisyon & 0,000 & Ret & $\mathrm{e}$ \\
\hline \multirow{8}{*}{$\begin{array}{l}\text { Kuruma Personel Alınırken KPSS Puanı Şart Olmalıdır } \\
\text { Düşüncesinin Bağımsız Değişkenlere Göre Anlamlı } \\
\text { Farklılık Gösterip Göstermediği. }\end{array}$} & Cinsiyet & 0,046 & Ret & $\mathrm{c}$ \\
\hline & Eğitim & 0,491 & Kabul & $\mathbf{a}$ \\
\hline & Kurum & 0,051 & Kabul & b \\
\hline & Bölge & 0,699 & Kabul & $\mathbf{a}$ \\
\hline & Yerleşim Yeri & 0,360 & Kabul & $\mathbf{a}$ \\
\hline & Statü & 0,013 & Ret & $\mathrm{c}$ \\
\hline & Maaş & 0,912 & Kabul & $\mathbf{a}$ \\
\hline & Pozisyon & 0,000 & Ret & $\mathrm{e}$ \\
\hline \multirow{8}{*}{$\begin{array}{l}\text { İşe Alınmada Yönetim Kurulunun Katkısının Olduğu } \\
\text { Düşüncesinin Bağımsız Değişkenlere Göre Anlamlı } \\
\text { Farklılık Gösterip Göstermediği }\end{array}$} & Cinsiyet & 0,091 & Kabul & $\mathbf{a}$ \\
\hline & Eğitim & 0,030 & Ret & $\mathrm{d}$ \\
\hline & Kurum & 0,263 & Kabul & $\mathbf{a}$ \\
\hline & Bölge & 0,011 & Ret & $\mathrm{c}$ \\
\hline & Yerleşim Yeri & 0,656 & Kabul & $\mathbf{a}$ \\
\hline & Statü & 0,331 & Kabul & $\mathbf{a}$ \\
\hline & Maaş & 0,388 & Kabul & $\mathbf{a}$ \\
\hline & Pozisyon & 0,581 & Kabul & $\mathbf{a}$ \\
\hline \multirow{8}{*}{$\begin{array}{l}\text { Kuruma Personel Alınırken Yönetim Kurulu Yakını } \\
\text { Olmak Öncelik Tercih Sebebidir Düşüncesinin } \\
\text { Bağımsız Değişkenlere Göre Anlamlı Farklılık } \\
\text { Gösterip Göstermediği }\end{array}$} & Cinsiyet & 0,241 & Kabul & $\mathbf{a}$ \\
\hline & Eğitim & 0,103 & Kabul & $\mathbf{a}$ \\
\hline & Kurum & 0,115 & Kabul & $\mathbf{a}$ \\
\hline & Bölge & 0,000 & Ret & $\mathrm{e}$ \\
\hline & Yerleşim Yeri & 0,207 & Kabul & $\mathbf{a}$ \\
\hline & Statü & 0,083 & Kabul & $\mathbf{a}$ \\
\hline & Maaş & 0,030 & Ret & $\mathrm{c}$ \\
\hline & Pozisyon & 0,012 & Ret & $\mathrm{c}$ \\
\hline \multirow{8}{*}{$\begin{array}{l}\text { Yönetim Değişiklerinin Çalışanları Tedirgin Etmesinin } \\
\text { Bağımsız Değişkenlere Göre Anlamlı Farklılık } \\
\text { Gösterip Göstermediği }\end{array}$} & Cinsiyet & 0,340 & Kabul & $\mathbf{a}$ \\
\hline & Eğitim & 0,404 & Kabul & $\mathbf{a}$ \\
\hline & Kurum & 0,001 & Ret & $\mathrm{d}$ \\
\hline & Bölge & 0,000 & Ret & $\mathrm{e}$ \\
\hline & Yerleşim Yeri & 0,362 & Kabul & $\mathbf{a}$ \\
\hline & Statü & 0,015 & Ret & $\mathrm{c}$ \\
\hline & Maaş & 0,087 & Kabul & $\mathbf{a}$ \\
\hline & Pozisyon & 0,250 & Kabul & $\mathbf{a}$ \\
\hline
\end{tabular}

Odalar ve borsalarda çalışan personelin yaklaşık \%79’luk gibi önemli bir oranı kurumun ne iş yaptığını bilerek çalışmaya başladığını ifade etmiştir. Aynı oranda da kurumun çalışanı olmaktan memnuniyetlerini dile getirmişlerdir. \%43,17 gibi yüksek bir oran da odalar ve borsalar personelinde işlerini kaybetme endişesi bulunmaktadır. Personelin \%31'ine göre kurumda personelin sorunlarının çözümü yavaş yürümektedir. Aynı oranda ise personel, yönetim kuruluna sorunlarını iletme imkânı bulamamaktadırlar.

Personelin yaklaşık \%39'u iş başlangıcında hizmet içi eğitimden geçmediğini ifade etmiştir. Personelin yaklaşık \%35'i kuruma personel alınırken KPSS puanının şart olması gerektiğini vurgulamıştır. Çalışma ortamı ve çalışma koşulları ile ilgili yapılacak düzenlemelerde görüşünün alınmadığını söyleyen \%30'luk, Kurumlarının kariyer planlarını gerçekleştirmesinde kendisine olanaklar sunmadığını belirten \%32'lik bir oran bulunmaktadır.

Odalar ve borsalarda çalışan personelin \%60'ının işe alınmasında yönetim kurulunun katkısı olmuştur ve personelin yaklaşık \%43'ine göre kuruma personel alınırken Yönetim Kurulu yakını olmak öncelik tercih sebebidir. Personelin yaklaşık 1/3' ü son 1 içinde istifa etmeyi düşünmüştür. Ve yarısından fazlaya denk gelecek 
biçimde yaklaşık \%53' ü yönetim değişikliklerinin kendisini tedirgin ettiğini beyan etmiş̧ir. Dikkate değer bir husus olarak personelin yaklaşık \%29' u mobbingle karşı karşıya kaldığını belirtmiştir.

Oda ve borsalarda çalışan personeldeki işi kaybetme endişesi, eğitim, yerleşim yeri ve pozisyon bağımsız değişkenlerine göre istatiksel açıdan anlamlı fark göstermezken diğer bağımsız değişkenlere göre anlamlı fark ortaya çıkmaktadır. İşi kaybetme endişesi genel olarak \%41,17'lik orana sahiptir ve erkeklerin oranı kadınlara orana daha yüksek çıkmıştır. Kurumlara göre anlamlı fark çıkmasının sebebi deniz ticaret odası çalışanlarının "katılıyorum" cevabı verme oranının \%6,25 gibi oldukça düşük oranda olmasıdır. Bölge dağılımlarında Güneydoğu Anadolu Bölgesinde yaşayanlar en yüksek şekilde endişe duyar iken, Karadeniz Bölgesinde yaşayanlar nispeten daha az oranda endişe duymaktadır. 5590 sayılı Kanuna tabi personelin işlerini kaybetme endişesi 5174 sayılı Kanuna tabi personel ve taşeron personele göre oldukça düşük orandadır. Maaş miktarı arttıkça işi kaybetme endişesi de tersi oranda azalmaktadır.

Kurumda çalışmaya başladığında hizmet içi eğitim alınması sadece pozisyona göre anlamlı fark göstermekte iken, diğer bağımsız değişkenlere göre anlamlı farklılık bulunmamaktadır. İşe başlamada hizmet içi eğitimden geçmeme oranı \%38,84'lük ortalamaya sahiptir ve bu oran amir konumundaki personellerde daha fazla çıkmaktadır. $\mathrm{Bu}$, personelin işi ve mevzuatı iş başında öğrendiğini, tesadüfi ve kurumsal ve biçimsel olmayan eğitime tabi tutulduğunu göstermektedir.

Ankete katılanlarda kuruma personel alınırken KPSS puanı şart olmalıdır düşüncesi hakimdir ve bu düşünce cinsiyet, statü ve pozisyon bağımsız değişkenlerine göre istatiksel açıdan anlamlı fark gösterirken diğer bağımsız değişkenlere göre anlamlı fark göstermemektedir. "Katılıyorum" cevabı verme oranı erkeklerde oldukça yüksektir. 5174 sayılı Kanuna tabi personelin katılma oran1 5590 sayılı Kanuna tabi personele göre düşük olduğu dikkat çekmektedir. Çalışılan pozisyonlar anlamında bu soruya "katılıyorum" cevabı verme oranları dikkat çekmektedir. Genel olarak \%44,79'luk oran ticaret sicili müdürü ve yardımcısında \%65,79' a çıkmaktadır.

İşe alınmada yönetim kurulunun katkısının olduğu bölge ve eğitim bağımsız değişkenlerine göre anlamlı farklılık gösterir iken diğer bağımsız değişkenlere göre anlamlı bir fark göstermemektedir. İşe alınırken yönetim kurulunun katk1sı olduğunu söyleyenlerin oranı \%57,51' dir ve bu oran Doğu Anadolu Bölgesinde 73,17' ye çıkmaktadır.

Kuruma personel alınırken yönetim kurulu yakını olmak öncelik tercih sebebidir düşüncesi bölge, maaş ve pozisyon bağımsız değişkenlerine göre anlamlı fark gösterirken diğer bağımsız değişkenlerine göre anlamlı fark göstermemektedir. \%42,35lik genel orana göre kuruma personel alırken yönetim kurulu yakını olmak gerekir. Bu oran, Doğu Anadolu Bölgesinde \%70,73' e çıkmakta, Marmara Bölgesinde ise \%31,37' ye inmektedir. Bu ise bize, bölgelerin kurumsallaşma kültürünü yansıtmaktadır. Pozisyonlara göre taşeron personel kuruma personel alınırken yönetim kurulu yakını olmanın öncelik sebebi olduğunda neredeyse hemfikirdir. Bu oran, genel sekreterlerde çok daha düşmektedir.

Yönetim değişiklerinin çalışanları tedirgin etmesi kurum, bölge ve statü bağımsız değişkenlerine göre anlamlı farklılık gösterirken iken diğer bağımsız değişkenlere göre anlamlı fark oluşmamaktadır. Güneydoğu Anadolu Bölgesindekiler yönetim değişikliklerinde diğer bölgedekilere göre daha fazla tedirginlik duyarken Marmara Bölgesindekiler ise daha az tedirginlik duymaktadır. Burada şaşırtıcı olan ise Ege Bölgesindekilerin tedirginlik oranının 54,71 çıkmasıdır. Ancak genel olarak yönetim değişiklikleri iş güvencesi anlamında çalışanları tedirgin edecek düzeydedir.

\subsubsection{3.Özlük Haklarına Yönelik Elde Edilen Bulgular}

Özlük haklarına yönelik toplam 104 adet hipotez kurulmuştur. Kurulan hipotezler ve bunlara yönelik uygulanan çapraz test ile khi kare sonuçları aşağıdaki gibidir.

Tablo 8. Özlük Haklarına Yönelik Kurulan Hipotezlere Yönelik Uygulanan Çapraz Test İle Khi-Kare Sonuçları

\begin{tabular}{|c|c|c|c|c|}
\hline Hipotez Açıklaması & $\begin{array}{c}\text { Bağımsız } \\
\text { Değișkenler }\end{array}$ & $\begin{array}{c}\text { Khi Kare } \\
\text { Significiant } \\
\text { Değeri }\end{array}$ & Sonuç & Yorum \\
\hline \multirow{8}{*}{$\begin{array}{l}\text { Geçim Sıkıntısının Olmasının Bağımsız Değişkenlere Göre Anlamlı Farklılık } \\
\text { Gösterip Göstermediği. }\end{array}$} & Cinsiyet & 0,055 & Kabul & $\mathrm{b}$ \\
\hline & Eğitim & 0,167 & Kabul & $\mathrm{a}$ \\
\hline & Kurum & 0,07 & Kabul & $\mathrm{b}$ \\
\hline & Bölge & 0,109 & Kabul & $\mathrm{a}$ \\
\hline & Yerleşim Yeri & 0,391 & Kabul & $\mathrm{a}$ \\
\hline & Statü & 0,01 & Ret & $\mathrm{d}$ \\
\hline & Maaş & 0,00 & Ret & $\mathrm{e}$ \\
\hline & Pozisyon & 0,00 & Ret & $\mathrm{e}$ \\
\hline
\end{tabular}




\begin{tabular}{|c|c|c|c|c|}
\hline \multirow{8}{*}{$\begin{array}{c}\text { Personel Arasındaki Maaş Aralıklarının Dikkat Çekici Düzeyde Olduğu } \\
\text { Düşünncesinin Bağımsız Değişkenlere Göre Anlamlı Farklılık Gösterip } \\
\text { Göstermediği. }\end{array}$} & Cinsiyet & 0,337 & Kabul & $\mathrm{a}$ \\
\hline & Eğitim & 0,037 & Ret & $\mathrm{d}$ \\
\hline & Kurum & 0,118 & Kabul & $\mathrm{a}$ \\
\hline & Bölge & 0,151 & Kabul & $\mathrm{a}$ \\
\hline & Yerleşim Yeri & 0,01 & Kabul & $\mathrm{a}$ \\
\hline & Statü & 0,005 & Ret & $\mathrm{d}$ \\
\hline & Maaş & 0,000 & Ret & $\mathrm{e}$ \\
\hline & Pozisyon & 0,000 & Ret & $\mathrm{e}$ \\
\hline \multirow{8}{*}{$\begin{array}{c}\text { Personele Verilen Maaşların Yetki, Görev Ve Sorumluluk Dikkate Alınarak } \\
\text { Belirlenmediği Düşüncesinin Bağımsız Değişkenlere Göre Anlamlı Farklılık } \\
\text { Gösterip Göstermediği. }\end{array}$} & Cinsiyet & 0,240 & Kabul & $\mathrm{a}$ \\
\hline & Eğitim & 0,022 & Ret & $\mathrm{c}$ \\
\hline & Kurum & 0,174 & Kabul & $\mathrm{a}$ \\
\hline & Bölge & 0,315 & Kabul & $\mathrm{a}$ \\
\hline & Yerleşim Yeri & 0,462 & Kabul & $\mathrm{a}$ \\
\hline & Statü & 0,169 & Kabul & $\mathrm{a}$ \\
\hline & Maaș & 0,000 & Ret & $\mathrm{e}$ \\
\hline & Pozisyon & 0,000 & Ret & $\mathrm{e}$ \\
\hline \multirow{8}{*}{$\begin{array}{c}\text { Başka Oda/Borsalarda Kendisiyle Aynı İşi Yapan Personelin Daha Fazla Özlük } \\
\text { Haklarına Sahip Olduğu Düşüncesinin Bağımsız Değişkenlere Göre Anlamlı } \\
\text { Farklılık Gösterip Göstermediği }\end{array}$} & Cinsiyet & 0,160 & Kabul & $\mathrm{a}$ \\
\hline & Eğitim & 0,736 & Kabul & $\mathrm{a}$ \\
\hline & Kurum & 0,225 & Kabul & $\mathrm{a}$ \\
\hline & Bölge & 0,011 & Ret & $\mathrm{c}$ \\
\hline & Yerleşim Yeri & 0,069 & Kabul & $\mathrm{a}$ \\
\hline & Statü & 0,926 & Kabul & $\mathrm{a}$ \\
\hline & Maaş & 0,001 & Ret & $\mathrm{e}$ \\
\hline & Pozisyon & 0,003 & Ret & $\mathrm{e}$ \\
\hline \multirow{8}{*}{$\begin{array}{l}\text { Sehir Dışında Tedavide Problem Yaşandığı Düşüncesinin Düš̈uncesinin } \\
\text { Bağımsız Değişkenlere Göre Anlamlı Farklılık Gösterip Göstermediği }\end{array}$} & Cinsiyet & 0,081 & Kabul & $\mathrm{a}$ \\
\hline & Eğitim & 0,014 & Ret & $\mathrm{c}$ \\
\hline & Kurum & 0,000 & Ret & $\mathrm{e}$ \\
\hline & Bölge & 0,003 & Ret & $\mathrm{d}$ \\
\hline & Yerleşim Yeri & 0,167 & Kabul & $\mathrm{a}$ \\
\hline & Statü & 0,317 & Kabul & $\mathrm{a}$ \\
\hline & Maaş & 0,673 & Kabul & $\mathrm{a}$ \\
\hline & Pozisyon & 0,000 & Ret & $\mathrm{e}$ \\
\hline \multirow{8}{*}{$\begin{array}{c}\text { Kurumda Yapılan Atama Ve Terfilerde Liyakate Dikkat Edilmediği } \\
\text { Düşüncesinin Bağımsız Değişkenlere Göre Anlamlı Farklılık Gösterip } \\
\text { Göstermediği }\end{array}$} & Cinsiyet & 0,930 & Kabul & $\mathrm{a}$ \\
\hline & Eğitim & 0,421 & Kabul & $\mathrm{a}$ \\
\hline & Kurum & 0,103 & Kabul & $\mathrm{a}$ \\
\hline & Bölge & 0,089 & Kabul & $\mathrm{a}$ \\
\hline & Yerleşim Yeri & 0,002 & Ret & $\mathrm{d}$ \\
\hline & Statü & 0,055 & Kabul & $\mathrm{a}$ \\
\hline & Maaş & 0,000 & Ret & $\mathrm{e}$ \\
\hline & Pozisyon & 0,000 & Ret & $\mathrm{e}$ \\
\hline \multirow{8}{*}{$\begin{array}{l}\text { Personeli Ödüllendirilme Mekanizmalarının İşletilmediği Düşüncesinin } \\
\text { Bağımsız Değişkenlere Göre Anlamlı Farklılık Gösterip Göstermediği }\end{array}$} & Cinsiyet & 0,922 & Kabul & $\mathrm{a}$ \\
\hline & Eğitim & 0,561 & Kabul & $\mathrm{a}$ \\
\hline & Kurum & 0,026 & Ret & $\mathrm{c}$ \\
\hline & Bölge & 0,056 & Kabul & $\mathrm{b}$ \\
\hline & Yerleşim Yeri & 0,892 & Kabul & a \\
\hline & Statü & 0,591 & Kabul & $\mathrm{a}$ \\
\hline & Maaş & 0,010 & Ret & $\mathrm{c}$ \\
\hline & Pozisyon & 0,001 & Ret & $\mathrm{d}$ \\
\hline \multirow{8}{*}{$\begin{array}{c}\text { Her Türlü Ödüllendirme Ve Terfilerde Bireysel Performans Değerlendirme } \\
\text { Sonuçları Esas Alınmadığı Düşüncesinin Bağımsız Değişkenlere Göre Anlamlı } \\
\text { Farklılık Gösterip Göstermediği }\end{array}$} & Cinsiyet & 0,350 & Kabul & $\mathrm{a}$ \\
\hline & Eğitim & 0,040 & Ret & $\mathrm{c}$ \\
\hline & Kurum & 0,198 & Kabul & $\mathrm{a}$ \\
\hline & Bölge & 0,098 & Kabul & $\mathrm{a}$ \\
\hline & Yerleşim Yeri & 0,437 & Kabul & $\mathrm{a}$ \\
\hline & Statü & 0,159 & Kabul & $\mathrm{a}$ \\
\hline & Maaş & 0,205 & Kabul & $\mathrm{a}$ \\
\hline & Pozisyon & 0,003 & Ret & $\bar{d}$ \\
\hline \multirow{8}{*}{$\begin{array}{l}\text { Bir Sendikaya Üye Olma Hakkının Olduğunu Bilmemenin Bağımsız } \\
\text { Değişkenlere Göre Anlamlı Farklılık Gösterip Göstermediği }\end{array}$} & Cinsiyet & 0,260 & Kabul & $\mathrm{a}$ \\
\hline & Eğitim & 0,617 & Kabul & $\mathrm{a}$ \\
\hline & Kurum & 0,909 & Kabul & $\mathrm{a}$ \\
\hline & Bölge & 0,064 & Kabul & $\mathrm{b}$ \\
\hline & Yerleşim Yeri & 0,504 & Kabul & $\mathrm{a}$ \\
\hline & Statü & 0,718 & Kabul & $\mathrm{a}$ \\
\hline & Maaş & 0,395 & Kabul & $\mathrm{a}$ \\
\hline & Pozisyon & 0,034 & Ret & $\mathrm{d}$ \\
\hline \multirow{8}{*}{$\begin{array}{l}\text { Başka Bir Odaya/Borsaya Tayin Hakkının Olmasını İsteğinin Bağıısız } \\
\text { Değişkenlere Göre Anlamlı Farklılık Gösterip Göstermediği }\end{array}$} & Cinsiyet & 0,814 & Kabul & $\overline{\mathrm{a}}$ \\
\hline & Eğitim & 0,209 & Kabul & $\mathrm{a}$ \\
\hline & Kurum & 0,000 & Ret & $\mathrm{e}$ \\
\hline & Bölge & 0,055 & Kabul & $\mathrm{a}$ \\
\hline & Yerleşim Yeri & 0,138 & Kabul & $\overline{\mathrm{a}}$ \\
\hline & Statü & 0,201 & Kabul & $\mathrm{a}$ \\
\hline & Maaş & 0,301 & Kabul & $\mathrm{a}$ \\
\hline & Pozisyon & 0,012 & Ret & $\mathrm{c}$ \\
\hline & Cinsiyet & 0,494 & Kabul & $\mathrm{a}$ \\
\hline 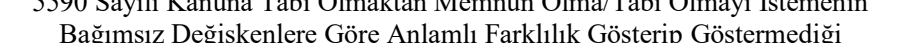 & Eğitim & 0,453 & Kabul & $\mathrm{a}$ \\
\hline & Kurum & 0,000 & Ret & e \\
\hline
\end{tabular}


AYDEMİR, Süleyman Ruhi - Türk Kamu Yönetiminde Ticaret Odaları ve Ticaret Borsaları Personeli Sorunu Araştırması

\begin{tabular}{|c|c|c|c|c|}
\hline & Bölge & 0,261 & Kabul & $\mathrm{a}$ \\
\hline & Yerleşim Yeri & 0,026 & Ret & $\mathrm{c}$ \\
\hline & Statü & 0,001 & Ret & $\mathrm{d}$ \\
\hline & Maaş & 0,024 & Ret & $\mathrm{c}$ \\
\hline & Pozisyon & 0,006 & Ret & $\mathrm{e}$ \\
\hline \multirow{8}{*}{$\begin{array}{l}5174 \text { Sayılı Kanuna Tabi Olmaktan Memnun Olma/Tabi Olmayı İstemenin } \\
\text { Bağımsız Değişkenlere Göre Anlamlı Farklılık Gösterip Göstermediği }\end{array}$} & Cinsiyet & 0,103 & Kabul & $\mathrm{a}$ \\
\hline & Eğitim & 0,006 & Ret & $\mathrm{d}$ \\
\hline & Kurum & 0,135 & Kabul & $\mathrm{a}$ \\
\hline & Bölge & 0,139 & Kabul & $\mathrm{a}$ \\
\hline & Yerleşim Yeri & 0,011 & Ret & $\mathrm{c}$ \\
\hline & Statü & 0,000 & Ret & $\mathrm{e}$ \\
\hline & Maaş & 0,000 & Ret & $\mathrm{e}$ \\
\hline & Pozisyon & 0,000 & Ret & $\mathrm{e}$ \\
\hline \multirow{8}{*}{$\begin{array}{c}\text { Devlette Kamu Çalışanı Statüsüne Alınma İsteğinin Bağımsız Değişkenlere } \\
\text { Göre Anlamlı Farklılık Gösterip Göstermediği }\end{array}$} & Cinsiyet & 0,941 & Kabul & $\mathrm{a}$ \\
\hline & Eğitim & 0,788 & Kabul & $\mathrm{a}$ \\
\hline & Kurum & 0,076 & Kabul & $\mathrm{b}$ \\
\hline & Bölge & 0,087 & Kabul & $\mathrm{a}$ \\
\hline & Yerleşim Yeri & 0,185 & Kabul & $\mathrm{a}$ \\
\hline & Statü & 0,021 & Ret & $\mathrm{c}$ \\
\hline & Maaş & 0,000 & Ret & $\mathrm{e}$ \\
\hline & Pozisyon & 0,619 & Kabul & $\mathrm{a}$ \\
\hline
\end{tabular}

Geçim sıkıntısının olmasının kurum, statü, maaş ve pozisyon bağımsız değişkenlerine göre anlamlı farklılık gösterir iken diğer bağımsız değişkenlerine göre istatistiksel olarak anlamlı fark bulunmamaktadır. Bunun sebebi, "Geçim sıkıntısı çekiyorum" sorusuna "katılıyorum" cevabı verenlerin oranı kurumlara göre ortalama \%59,83 iken, aynı oran 5590 sayılı Kanuna tabi personelde \% 45,37, 5174 sayılı personelde \%60,47, taşeron işçilerde \% 83,33 şeklinde değişmesi, bu oranın aylık ortalama maaşlara göre çapraz dağılımında \% 75,53 'ten \%26,37'ye inecek şekilde maaş miktarı arttıç̧a azalması ve pozisyonlara göre oranın değişmesinden kaynaklanmaktadır.

Odalar ve borsalar personeli personel arasındaki maaş aralıklarını dikkat çekici düzeyde olduğu düşüncesindedir ve bu düşünce eğitim, statü, maaş ve pozisyon bağımsız değişkenlerine göre anlamlı fark gösterir iken diğer bağımsız değişkenlere göre anlamlı farklılık oluşmamaktadır. Bunun sebebi; "Personel arasındaki maaş aralıkları dikkat çekici düzeydedir" sorusuna "katılıyorum" cevabı verenlerin oranı, eğitim seviyesi arttıkça düşmesinden, 5590 sayılı Kanuna tabi personelin soruya "katılıyorum" cevabı verme oranının 5174 sayılı Kanuna tabi personele göre oldukça düşük olmasından, yüksek maaş alan personelin daha düşük maaş alanlara göre oransal olarak daha düşük "katılıyorum" cevabı vermesinden ve Genel Sekreter pozisyonunda olan personelin diğer personele göre maaş aralıklarının dikkat çekici bulmamasından kaynaklanmaktadır.

Personele verilen maaşların yetki, görev ve sorumluluk dikkate alınarak belirlenmediği düşüncesi eğitim, maaş ve pozisyon bağımsız değişkenlere göre anlamlı farklılık gösterir iken diğer bağımsız değişkenlere göre anlamlı fark çıkmamaktadır. Bunun sebebi "Personele verilen maaşlar yetki, görev ve sorumluluk dikkate alınarak belirlenmektedir" sorusuna "katılıyorum" cevabı verenlerin oranının eğitim seviyesi yükseldikçe azalmasından, yüksek maaş alanların oransal olarak daha yüksek bir şekilde katılıyorum demesinden ve amir konumundaki Genel Sekreterlerin oransal olarak daha yüksek şekilde katılıyorum cevabı vermesinden kaynaklanmaktadır.

Personel, başka oda/borsalarda kendisiyle aynı işi yapan personelin daha fazla özlük haklarına sahip olduğu düşüncesine sahiptir ve bu düşünce bölge, maaş ve pozisyon bağımsız değişkenlere göre anlamlı farklılık gösterir iken diğer bağımsız değişkenlere göre anlamlı fark çıkmamaktadır. Bunun sebebi; "Başka Oda/Borsalarda benimle aynı işi yapan daha fazla özlük haklarına sahiptir" cümlesine "katılıyorum" cevabı verenlerin bölgesel anlamda oranların farklı olmasından kaynaklanmaktadır. Öyle ki, Marmara Bölgesinde yaşayanlar bu soruya \%52,29'luk oranla katılıyorum derken bu oran İç Anadolu Bölgesinde \%71,43'e, Doğu Anadolu Bölgesinde ise \%80,49'a çıkmaktadır. Ayrıca maaşı miktar olarak yüksek olanlar daha düşük oranda katılırlarken, miktar olarak maaşı yüksek olan Genel Sekreterlerin başka oda ve borsalarda kendileriyle aynı işi yapan kişilerin daha fazla özlük hakkına sahip olduğunu belirtme oranı $\% 67,89$ gibi oldukça yüksek orana sahiptir.

Personel şehir dışında tedavide problem yaşandığı düşüncesindedir ve bu düşünce eğitim, kurum, bölge ve pozisyon bağımsız değişkenlerine göre anlamlı farklılık gösterir iken diğer bağımsız değişkenlere göre anlamlı fark çıkmamaktadır. "Şehir dışında hastalandığımda hastaneye gidip tedavide problem yaşıyorum" sorusuna "katılıyorum" cevabı verenlerin oranı eğitim düzeyi arttıkça ve pozisyonlar değiştikçe yükselmektedir. Bunun sebebi, personelden şehir dışına yapılan görevlendirmelerin çoğunluğunun pozisyon itibarıyla Genel sekreterler, yardımcıları ile Ticaret Sicili Müdürü ve yardımcısı olması ve bunların şehir dışında rahatsızlanma ihtimallerinin yüksek olmasından kaynaklanmaktadır. Ayrıca, kurum türü bağlamında da değişkenlik gösteren "katılıyorum" cevabının sebebi ticaret sicili personelinin sadece ticaret odas ile ticaret ve sanayi odalarında 
istihdam ediliyor olmasıdır. Öte yandan, bölgelerin gelişmişlik düzeyleri ile "katılıyorum" cevaplarının ters orantılı olduğu ortaya çıkmaktadır. Marmara bölgesi oransal olarak düşük iken, Güneydoğu Anadolu Bölgesi oransla olarak en yüksek orana sahiptir.

Kurumda yapılan atama ve terfilerde liyakate dikkat edilmediği düşüncesi yerleşim yeri, maaş ve pozisyon bağımsız değişkenlere göre anlamlı farklılık gösterir iken diğer bağımsız değişkenlere göre anlamlı fark çıkmamaktadır. "Kurumumda yapılan atama ve terfilerde liyakate dikkat edilmektedir" sorusuna "katılıyorum" cevabı verme oranının ilçe yerleşim yerlerinde daha fazla çıkma oranının sebebi ilçelerdeki kurum personel sayısının azlığından kaynaklanmaktadır. Ayrıca, maaş miktarı arttıkça "katılıyorum" cevabı verme oranının düşmesi kazanç ile fikir arasındaki bağlantıyı net bir şekilde ortaya koymaktadır. Kişiler gelirleri arttıkça liyakatin olduğunu savunmaktadır. Aynı durum pozisyonlar için de geçerlidir. Amir konumunda olan genel sekreterler ve yardımcılarda oran yüksek iken diğer personelde oran düşmektedir.

Personeli ödüllendirilme mekanizmalarının işletilmediği düşüncesi kurum, maaş ve pozisyon bağımsız değişkenlere göre anlamlı farklılık gösterir iken diğer bağımsız değişkenlere göre anlamlı fark çıkmamaktadır. "Yönetim tarafından çalışanları ödüllendirme (teşekkür yazıları, ek ödeme ilave puanı, vb.) mekanizmaları işletilmektedir" sorusuna "Katılmıyorum" cevabı verme oranı kurumlara göre birbirine yaklaşık biçimde değişkenlik göstermektedir. Ayrıca, maaş yükseldikçe katılmama oranı da doğal olarak düşmekte, benzer şekilde amir pozisyonunda olan genel sekreter ve yardımcısı pozisyonlarında olanlara göre personele ödüllendirme mekanizması işletilmektedir.

Her türlü ödüllendirme ve terfilerde bireysel performans değerlendirme sonuçları esas alınmadığı düşüncesinin eğitim ve pozisyon bağımsız değişkenlere göre anlamlı farklılık gösterir iken diğer bağımsız değişkenlere göre anlamlı fark çıkmamaktadır. "Her türlü ödüllendirme ve terfilerde bireysel performans değerlendirme sonuçları esas alınmaktadır" sorusuna "katılmıyorum" şeklinde cevap verenlerin oranı ilköğretim, lisans ve yüksek lisans mezunu kişilerde daha yüksek iken diğerlerine göre daha düşüktür. Amir pozisyonunda olan Genel Sekreterlerin katılmama oranı diğerlerine göre daha düşüktür. Esasında \%32,11 oranında katılmıyorum cevabı veren genel sekreterlerdeki bu oranın ödüllendirme hususunun ana aktörü olmaları nedeniyle daha düşük çıkması gerekmektedir.

Bir sendikaya üye olma hakkının olduğunu bilmeme sadece pozisyon anlamında anlamlı farklılık gösterir iken diğer bağımsız değişkenlere göre anlamlı fark çıkmamaktadır. Sendika hakkı olduğunu bilmeme oranı genel olarak 52,64'lük bir yüzdeye sahip iken bu oran amir konumundaki genel sekreter ve yardımcılarında sirasıyla $\% 55,96$ ve $\% 61,90$ oranına çıkmaktadır.

Başka bir odaya/borsaya tayin hakkının olması isteği kurum ve pozisyon bağımsız değişkenlere göre anlamlı farklılık gösterir iken diğer bağımsız değişkenlere göre anlamlı fark çıkmamaktadır. Bu soruya "katılıyorum" cevabı verenlerin oranı genel olarak \% 75,64'lük orana sahipken deniz ticaret odasında çalışanlarında bu oran \%31,25'e kadar düşmektedir. Bunun sebebi Deniz Ticaret Odasının sayısının ülkemizde sadece 2 adet olmasından kaynaklanmaktadır. Ayrıca, katılma oranı pozisyonlara göre değişkenlik göstermektedir.

5590 sayılı Kanuna tabi olmaktan memnun olma/tabi olmayı isteme, bölge, eğitim ve cinsiyet bağımsız değişkenlere göre anlamlı fark göstermez iken diğer bağımsız değişkenlere göre anlamlı fark göstermektedir. "5590 Sayıl1 Kanuna tabi olmaktan memnunum/tabi olmay1 isterdim" sorusuna "kat1liyorum" cevab1 verme oranı genel olarak \% 61,84 iken Deniz Ticaret Odasında \%7,14'e düşmektedir. Pozisyon ve statü anlamında farklı çıkmasının sebebi taşeron personelde bu oranın \%50 oranına düşmesi ve muhtemelen sorunun anlamını bilmemelerinden kaynaklanmaktadır. Yerleşim yerleri bağlamında kararsızların oranının anlamlı farklılığı etkilediği düşünülmektedir. Statü hukukunun vermiş olduğu iş güvencesi soruya verilen cevabın oranında yatmaktadır. Birbirine yakın oranlar olsa bile eğitim düzeyi yükseldikçe katılma oranı da düşmektedir.

5174 sayılı Kanuna tabi olmaktan memnun olma/tabi olmayı isteme ise kurum, bölge ve cinsiyet bağımsız değişkenlere göre anlamlı fark göstermez iken diğer bağımsız değişkenlere göre anlamlı fark göstermektedir. "5174 sayılı Kanuna tabi olmaktan memnunum/tabi olmayı isterdim" sorusuna "kat1liyorum" cevabı verenler \%29,96 gibi oldukça düşük orandadır. Anlamlı fark çıkmasının sebebi taşeron işçilerin bu soruyu anlamamalarından kaynaklanmaktadır. Maaş miktarı arttıkça katılma oranı da artmaktadır.

Devlette kamu çalışanı statüsüne alınma isteği statü ve maaş bağımsız değişkenlerine göre anlamlı farklılık gösterir iken diğer bağımsız değişkenlere göre anlamlı fark göstermemektedir. Oransal olarak \%89,17’lük orana sahip "katılıyorum" cevabı, maaş miktarı arttıkça düşmektedir. Ayrıca, statüye göre anlamlı fark çıkma khi kare test sonucu 0,021 gibi kritik eşiğe yakın olduğundan veri sayısı arttıkça anlamlı fark çıkmama ihtimali çok fazladir. 


\section{SONUÇ}

Kuruluş dayanağını anayasamızın 135'nci maddesiyle almış bulunan kamu kurumu niteliğindeki meslek kuruluşları ve üst kuruluşları; belli bir mesleğe mensup olanların müşterek ihtiyaçlarını karşılamak, mesleki faaliyetlerini kolaylaştırmak, mesleğin genel menfaatlere uygun olarak gelişmesini sağlamak, meslek mensuplarının birbirleri ile ve halk ile olan ilişkilerinde dürüstlügü ve güveni hâkim kılmak üzere meslek disiplinini ve ahlakını korumak maksadı ile kanunla kurulan ve organları kendi üyeleri tarafindan kanunda gösterilen usullere göre yargı gözetimi altında, gizli oyla seçilen kamu tüzel kişilikleridir ve ortaya çıkış nedeni, kamu hizmeti niteliğine sahip bazı faaliyetlerin topluma daha faydalı hale getirilmesi amacıyla düzenlenmesi gereğinden kaynaklanmaktadır.

13. yy'da ortaya çıkan ahilik sisteminde yer alan fütüvvetnameden hâlihazırda geçerli olan 5174 sayılı kanuna gelen evrilme sürecinde oda ve borsalarda kamusal görüntünün ön plana çıkması dikkati çekmektedir. Cumhuriyetin ilanı ile birlikte anayasal çerçevede ilk defa 1961 anayasasında ye rini bulması, daha sonraki dönemde ise daha geniş bir düzenleme ile 1982 anayasasında yerini alması odalar ve borsaların kamusal yönünün daha ağır basmasına yol açmıştır.

1943 sayılı kanunla ticaret, sanayi ve küçük sanat erbabı ve esnaf topluca teşkilatlandırılarak şahsiyetlendirilen odalar, kamu hizmetlerinin yürütülmesinde resmî makamların yardımcı organları olarak görülmüş, kuruluş ve özellikle görevleri itibariyle, kamu kurumu karakterine sahip olmuşlardır. Bu dönemde; Ticaret Bakanlığı, odaların her birinin nezdinde, bir genel sekreter ve gerektiğinde bir de genel sekreter yardımcısı atamasına yetkili kılınmıştır. 1950 yılında ise 5590 sayılı "Ticaret ve Sanayi Odaları ve Ticaret Borsaları Birliği” kanunu çıkartılarak bu kuruluşlar özerklik kazanmıştır.

Tarihsel süreç içerisinde bu kuruluşlarda istihdam edilen personelin hukuki durumları da evrilmiştir. 08.03.1950 tarihli 5590 sayılı kanunu'ndan önce odalar ve borsalarda istihdam edilen personelin hukuksal durumlarını ortaya koyacak bütün oda ve borsalar için geçerli olacak yazılı bir metin ve yasal bir dayanak yoktur. 1943 tarihine kadar odalarda ve borsalarda istihdam edilmiş tüm personel, odaların ve borsaların kuruluşları tarafından değişik tarihlerde çıkarılmış ayrı ayrı metinlere göre bu kuruluşların karar organlarınca atanmakta, ancak bu metinlerde atanmanın usul ve esaslarına yönelik açıklama bulunmamaktadır. 1943 yılında çıkarılan 4355 sayılı Ticaret ve Sanayi Odaları, Esnaf Odaları ve Ticaret Borsaları Kanunu ve bu kanun'un uygulanması ile ilgili olarak konulan 2/19900 sayılı Ticaret ve Sanayi Odaları, Esnaf Odaları ve Ticaret Borsaları Nizamnamesi, odalar ve borsalar için bazı ortak düzenlemeler getirmiştir. Bu dönemde oda ve borsa genel sekreterleri ve yardımcıları Ticaret Bakanlığınca atanmaktadır. Odalar ve borsalarda çalışan diğer personel; memurlar ve hizmetliler olarak ikili bir sınıflandırmaya tabi tutulmuş, bu personelin atanması, yükselmesi, disiplin işlemleri ve görevine son verilmesindeki tüm yetkiler yönetim kurullarına verilmiştir. Ancak bunların nasıl yapılacağını gösterir usul ve esaslar belirlenmemiştir.

5590 sayılı kanuna bağlı olarak 1983 tarihinde personel yönetmeliği yayımlanmış ve bu kuruluşlardaki personele ortak hükümler getirilmiş ve personeli memurlar, sözleşmeli ve geçici personel ile hizmetliler olarak sınıflandırmış, bu personelin ödev ve sorumlulukları ile onlar için konulan yasaklar ise 657 sayılı Devlet Memurları Kanunu ile ilişkilendirilmiştir.1984 tarihinde ise sicil işlemlerine yönelik olarak Personel Sicil Yönetmeliği yayımlanmıştır.

01.06.2004 tarihli 5174 sayılı kanun, tüm düzenlemeleri bir kenara bırakarak buralarda istihdam edilen personel ile iş kanunu özdeşleştirilmiştir. $O$ anda hali hazırdaki personelin statülerinin devam edeceği hüküm altına alınmış, o tarihten sonra işe alınanların ise iş kanununa tabi oldukları hüküm altına alınmıştır. Böylelikle odalar ve borsalarda statü hukuku uygulanan personel ile iş hukukuna tabi esnek hukuk uygulanan iki farklı personel rejimi ortaya çıkmıştır.

Odalar ve borsaların esas üretim alanının kamu hizmeti olması, personele yönelik hukuki dayanağın evrilme süreci içeresinde, buralarda istihdam edilen personel ile odalar ve borsalar arasındaki çalışma ilişkisi, özünü statülerde bulan statüsel çalışma ilişkisi ve özünü sözleşmede bulan sözleşmesel çalışma sistemi olarak ikiye ayrılmıştır (Gülmez, 1996:3).

Statüsel çalışma ilişkisinde çalışanın devlet ile olan ilişkilerinin kural olarak yasa ile belirlenmesi, temel haklar, ödev ve sorumlulukların mevzuat ile ortaya konması, statü çalışma ilişkisinin ana unsurları olan güvence, süreklilik, tarafsızlık ilkeleri sözleşmesel çalışma sisteminde belirsizliğe doğru gitmiştir. 
Geleneksel kamu yönetiminin Yeni Kamu Yönetimi (YKİ) anlayışına dönüşümünün yansıması olarak oda ve borsalarda personel istihdamında bu dönüşüme uygun istihdam politikalarının getirilmesi, böylelikle işe alınma, eğitim, hak ve sorumluluklar, yasaklar ve özellikle ise son vermede tamamen odalar ve borsalar yönetimi ile çalışanlar arasında yapılan sözleşmeye dayanmasına yol açmıştır.

Oda ve borsalarda 5174 sayılı kanun öncesi istihdam edilmeye başlanılan personelin kamu görevlisi olduğuna yönelik yargı kararlarında yerini bulan ve yeri sağlamlaşan personelden İş Kanununa tabi ve sözleşmeye dayalı işçi niteliğine yönelik personele dönüşen anlayışın tezahürü olarak çalışma ilişkilerinde en önemli olarak görülen "iş güvencesi" kavramı rafa kalkmış görünmektedir. İş hukukunun temel mantı̆̆ında yer alan haksız yere iş çıkarma karşılığı ödenilen tazminatların anlamı, haksız yere işten çıkartan kişilerin (yönetim kurulu) bu tazminatları kurum bütçesinden ödemesi nedeniyle, kalmamaktadır. Odalar ve borsalarda 4 yılda bir yapılan seçimler sonucunda erki ellerine geçiren kişilerin ele geçirdikleri erki istediğini istihdam etme, özlük haklarını dilediği gibi düzenleme, kolaylıkla işten çıkarma yönünde kullanabilme özgürlüğü ve bu özgürlüğü kullanırken mevzuat dışı uygulamalardan kaynaklanan tazminatların kendi parasal kaynaklarından karşılanmayıp kurum bütçesinden karşılanması özgürlüğün sınırlarını genişletmektedir.

Geleneksel statü güvencesinde çalışanın ömür boyu istihdamı temel ilkedir. Oysa sözleşmesel çalışma ilkesinde bu iş güvencesi bulunmamakta, belirli süreli sözleşmelerle işe alınan personelin işinin korunması amirin değerlendirdiği performansa bağlı hale getirilmiştir. Statü hukukuna bağlı, ömür boyu süreni katı kuralları olan ve güvenceli bir çalışma sisteminden sözleşme hukukuna bağl1, esnek kuralları olan ve güvencesi karar vericilere dayalı olan bir çalışma sistemine geçiş olmuştur.

Geleneksel statü güvencesinde çalışan merkezi bir personel rejimine tabidir. Tüm çalışanlar için uygulanacak hükümler ortaktır ve bu değişmez. Oysa sözleşmesel çalışma sisteminde her oda ve borsa kendi düzenlemesini kendisi yapar. Her kurum kendi personel rejimini kendisi oluşturmakta, hatta her çalışan için ayrı ayrı bir şekilde sözleşme ile düzenlenebilmektedir. Bu şekilde ortaya çıkan kurumlararası farklılaşma personel rejimini de alt üst etmiştir.

Oda ve borsalarda gerek 5590 sayılı kanun döneminde gerekse 5174 sayılı kanun döneminde sinavla işe alma genel kuralı ve rejimi yaygın değildir. Yani tüm odaları ve borsaları kapsayacak biçimde işe alma rejimi hiçbir şekilde uygulanmamıştır. İstihdam kurumsal düzeyde yapılmaktadır.

Kariyer yani kurum içinde derece ve kademe yükselmesi ve buna bağlı olarak maaş ve gösterge artışları belirli bir kurala tabi iken esnek çalışma düzeninde bundan tamamen vazgeçilmiştir. Derece ve kademe ilerlemesi ortadan kalktığı için buna bağlı olarak belirlenen maaş belirlenmesi ve yükseltmesi yönetim kurullarının insafına ve inisiyatifine terkedilmiş bulunmaktadır. İş Kanununa hakim olan eşit işe eşit ücret veya eşit işlem görme hakkı uygulama zeminini bulamamaktadır. Böylelikle değişik miktarlarda ücret alan personel yapısı ortaya çıkarak kurumsal barışı ortadan kaldırmıştır. Eksikleri olsa da 5590 sayılı kanun dönemindeki eşitlikçi, göreli, tek biçimli maaş rejimi farklılaşmış, eşitliksiz bir biçime ve rekabetçi bir yapıya kavuşmuştur. Maaş rejimi kurumsal ve bireysel düzeyde değişmiştir. Maaş artışları performansa göre belirlenmeye yönelen bir yapıya bürünmüştür. Hiyerarşideki pozisyona dayalı, diploma ve kıdemin dayandığı standart bir modelden performansa dayalı, farklılaştırılmış ücrete dayalı bir modele geçiş yapılmıştır.

Statüler çalışma ilişkisinde 5590 döneminde personelin sicillerinin değerlendirme usulleri belirli iken sözleşmesel çalışma düzeninde bir düzene bağlı olmayan sicil değerlendirme usulleri ortaya konmuştur. Perfromansın temel alındığı düzende bireysel performans ölçütleri doğrultusunda maaş artışları yapılmaktadır. Ancak performansların neye ve kime göre belirlendiği açık olmadığı için kurumsal olmayan ölçütler ön plana çıkmaktadır.

Sözleşmesel çalışma döneminde çalışanların statüsünden emekliliğine kadar her türlü uygulamaların sonucu olan iş güvencesizliği, çalışanlarda korku, endişe ve kaygıyı da beraberinde getirmiş̧tir. Çalışanların hizmet ilişkisinin yönetim kurulları tarafından haklı bir neden gösterilmeksizin sona erdirilmesini sınırlayan iş güvencesi statüler çalışma düzeninde idari yargıca korunurken, sözleşmesel çalışma düzeninde çoğunlukla ortadan kalkmıştır. Bu düzenin yarattı̆̆ı bireysel ve örgütsel sonuçları da göz ardı etmemek gerekmektedir. İş güvencesizliğinin yarattığı işten çıkarılma tehdidi çalışanların karar verme yetilerini de ellerinden almaktadır. İstihdamı sözleşmesel çalışma düzeneğinde yapılan çalışanların eylem ve işlemlerinin Türk Ceza Kanunundaki memur yargılanmaları çerçevesinde değerlendirilmesi iş kabiliyetini iyice sınırlar hale getirmiştir.

Odalar ve borsalarda sözleşmesel çalışma düzeneğine evrilen çalışma ilişkilerinde statüler çalışma düzeneğine hakim olan istihdam şartları da rafa kaldırılmıştır. Statüler çalışma düzeneğindeki istihdam edebilme şartları olarak uygulanan yasal metinlerde yer alan yaş, sağlık, adli sicil gibi asgari şartların artık bir hükmü 
AYDEMİR, Süleyman Ruhi - Türk Kamu Yönetiminde Ticaret Odaları ve Ticaret Borsaları Personeli Sorunu Araştırması

bulunmamaktadır. Bu keyfiyet ticaret sicili müdür ve yardımcılığının istihdamında ortaya konulan istihdam şartları ile kısmen de olsa önlenmiş ancak genel itibarıyla düzensiz bir personel politikasının önüne geçilmesini engelleyememiştir. Odalar ve borsalardaki düzensiz personel istihdamı, 4 yılda bir yapılan yönetim kurulları seçiminin ortaya çıkardığı nepotizm politikasının doğrusal bir sonucu olarak dikkati çekmektedir. Kurumlarda uzun vadeli herhangi bir personel politikası olmaması kurum ihtiyacı-istihdam ilişkisinden ziyade tanıdıklarını işe alma uygulamalarına dönüşmüştür. Bazı kurumların toplam personel sayısı 5 iken bunun 2 veya 3'ünün destek hizmetinde çalışan personel olması tesadüfi değildir.

Tersine bir durum olarak da; kurumların bütçelerinin özerk olması ve yetersiz olmaları da eğitim düzeyi yüksek personel alımını engellemektedir. Bu tür kurumlarda maaş yapısı asgari ücretle ilişkilendirildiği ve eğitim düzeyi yüksek personelin bu maaşla çalışmaya razı olmaması kurumlardaki personelin eğitim kalitesinin düşük olmasına sebep olmaktadır.

Odalar ve borsaların kendi kurumsal iç işleyişlerindeki personel uygulamalarının hemen hepsinin belirli bir rejime tabi olmaması, düzenek içerisinde yürümemesi, personel özlük haklarının verilmesi ve kullandırılmasında kanuni bir haktan öte lütufmuş gibi davranılması hem yasal hem de ussal biçimde uygulanmaması sonucunu doğurmaktadır. Hem personel bazında hem de kurumsal bazdaki düzeneksizlik kurum içi çalışma barışını da zedelemektedir.

Kişilerin çalışma ve ev geçindirme zorunluluğu ve işsiz kalma endişesi hakları verilmeyen personelin ses çıkaramamasına neden olmaktadır. İş hukukuna hakim olan ilkelerden işçinin korunması ilkesi ve bu ilkenin vermiş olduğu yargıya ve üst makamlara başvuru hakkı böylece sadece kağıt üzerinde kalan bir haktan öte anlam taşımamaktadır. Kamu kurumu olarak kabul edilen ve kamusal faaliyet yükümlülüğü bulunan odalar ve borsalarda yönetme erkine verilen istihdam serbestiyeti, kamusal faaliyetin mecbur kıldığ 1 işlemleri gerçekleştiren personelin gerçekleştirdiği bu faaliyetin yönetme erkine sahip olanların zararına bir sonuç olması halinde kötüye kullanılmaktadır. Bu serbestiyet genellikle yönetim erkinde başkan sıfatında toplandığı için kararların alınış biçimi tek kişi iradesine dayanmaktadır. Ticaret borsalarında tescil edilmemesi gereken bir alım satımın tescil ettirilme, ticaret odalarında tescili imkânsız bir hususunun tescil ettirilme yönündeki iradenin yasal yönden imkansız olması karşısında personel ile yönetim karşı karşıya kalmaktadır.

Odalar ve borsalarda statüler düzeneğinde çalışan personelin mevcut durumlarından memnun olması, sözleşmesel çalışma düzeneğinde çalışan personelin durumundan memnun olmaması ve statüler çalışma düzeneğinde yer alma isteği ve hem statüler hem de sözleşmesel çalışma düzeneğindeki personelin devlette kamu çalışanı statüsünde olma isteği, odalar ve borsaların kurumsal ve iç işleyiş, istihdam ve özlük hakları sorunlarını bir arada değerlendirildiğinde şaşırtıcı değildir. Araştırmada, odalarda ve borsalarda istihdam edilen 5590 sayılı kanuna tabi statü hukukuna bağlı personel ve 5174 sayılı kanuna tabi iş hukukuna tabi personel ile bu kuruluşların esas personeli olmayıp kuruluşlardaki çoğunluk itibarıyla yardımcı hizmetleri yerine getiren dışardan hizmet satın alma yoluyla çalıştırılan personelin kurumsallaşma ve iç işleyiş, istihdam sorunları ve özlük hakları ilgili 8 bağımsız değişken grup üzerinden analizler yapılmıştır.

Yapılan araştırma sonucunda; odalar ve borsalarda istihdam edilen personelin kendilerini istihdam eden yönetim kurulunun kurumu kendi işyerleri gibi yönettiğini belirtmeleri, en küçük aksaklıkta olumsuz tavır alındığını vurgulamaları, firsat ve imkânların adil ve şeffaf olarak tüm çalışanlara sunulmadığını, başarılarının takdir edilmediği, kararların demokratik şekilde alınmadığını, işlerine motive olmadıklarını belirtmeleri, kurum içinde yetki ve sorumlulukların dengeli şekilde dağıtılmadığını belirtmeleri kurumsallaşma ve iş işleyişteki sorunları göz önüne sermektedir.

Araştırma, odalar ve borsalarda çalışan personelin yüksek yoğunlukta iş kaybetme endişesi taşıdığını göstermektedir. Personelin işe alınmasında yönetim kurulunun katkısı olduğunu belirtmesine rağmen (muhtemelen yönetimin değişmesi durumunda) işini kaybetme endişesi taşıması dikkati çekecek bir durumdur. "Yönetim Kurulu yakını olmak", odalar ve borsalarda istihdamın ana şartı haline dönüşmüştür. Mülga 5590 sayılı kanun döneminde geçerli olan istihdam şartlarının 5174 sayılı kanun ile birlikte artık aranmamaya başlaması "Yönetim Kurulu yakını olmak" uygulaması ile bu kurumlarda kurumsallaşmanın tamamen rafa kalkmasına neden olmuştur. Bu istihdam rejimi kurum içi uygulamalara yansımakta, kurumda yapılan atama ve terfilerde liyakate dikkat edilmemekte, yazılı ve sözlü cezalandırmalarda personel arasında ayrım yapılmaktadır.

Alan araştırması çalışanların yarıdan fazlasının geçim sıkıntısı çektiğini ortaya koyar iken aynı zamanda çalışanlar arasındaki maaş aralıklarının dikkat çekici düzeyde, adil olmayan bir şekilde olduğunu göstermiştir. Bunun yanısıra maaşların yetki, görev ve sorumluluk dikkate alınarak belirlenmediği düşüncesi adil olmayan düzenin yansımasıdır. 
Çalışanların anayasal hakları olan yıllık izin, sağlık izni, mazeret izni gibi haklarını yeterince kullanamaması, tam zamanında mesaiden çıkamamaları, ikramiyelerini, fazla mesai ücretlerini zamanında ve eksiksiz alamamaları çalışanlara bakış açısının kurumsal düzeyde yansımalarıdır. Çalışanların örgütlenme özgürlüğünün kurumsal yansıması olan sendikalaşma bu kuruluşlara uğramamıştır. Çalışanlar adeta sendikalar tarafından keşfedilmeyi beklemektedir.

Alan araştırması, buralarda çalışan personelin kurumsallaşma, istihdam ve özlük hakları bağlamında mutsuz olduğu gerçeğini bizlere açık ve net göstermektedir. Personel kendilerine uygulanan istihdam rejiminden memnun olmadığını, iş güvencesizliği taşıdığını göstermiştir.

\section{KAYNAKÇA}

CRAMER, Duncan ve HOWITT, Dennis Laurence (2004), The SAGE Dictionary of Statistics: A Practical Resource For Students in The Social Sciences, Sage Publications, Londra.

EDMONDSON, Diane R. (2005), "Likert Scales: A History", Proceedings of The 12th Conference on Historical Analysis And Research in Marketing (Ed. Leighann C. Neilson), (CHARM), 28 Nisan-1 Mayis 2005, Sage: Thousand Oaks, Long Beach - CA - USA, ss.127-133, http://faculty.quinnipiac.edu/charm (Erişim Tarihi: 18.11.2017).

ERYILMAZ, Bilal (2009), Kamu Yönetimi, Okutman Yayınc1lık, Ankara, 2.Bask1.

GÖZLER, Kemal (2003), İdare Hukuku, Ekin Yayınları, Bursa, C.1.

GÖZÜBÜYÜK, A. Şeref (2010), Türkiye'nin Yönetim Yapısı, Turhan Kitapevi, Ankara, 11.Baskı.

GÖZÜBÜYÜK, Şeref, TAN, Turgut (2011), İdare Hukuku, Cilt 1, Turhan Kitabevi, Ankara.

GÜLMEZ, Mesut (1996), Dünyada Memurlar ve Sendikal Haklar, TODAİE Yayınları, Ankara.

GÜNDAY, Metin (2011), İdare Hukuku, İmaj Yayınları, Ankara, 10.Bask1.

İSLAMOĞLU, Ahmet Hamdi ve ALNIAÇIK, Ümit (2016), Sosyal Bilimlerde Araştırma Yöntemleri, Beta Yayınları, İstanbul.

KAYIŞ, Aliye (2010), “Güvenirlilik Analizi”, SPSS Uygulamalı Çok Değişkenli İstatistik Teknikleri (Ed. Şeref KALAYLI), Asil Yayınları, Ankara, 5.Bask1, ss.404-419.

ÖZER, Atilla (1994), Türkiye'de Kamu Kurumu Niteliğinde Meslek Kuruluşları (Anayasa Hukuku Açısından), TUGİAD Yayınları, Ankara.

PARLAK, Bekir ve SOBACI, Zahid (2012), Kamu yönetimi, MKM Yayınları, Bursa, 4.Bask1.

TAN, Turgut (2013), İdare Hukuku, Turhan Kitabevi, Ankara.

TOBB (2017), 2016 Faaliyet Raporu ve 2018 Yııı İş Programı ve Bütçesi, TOBB Yayını, Ankara.

YÜCEL TOY, Banu ve GÜNERİ TOSUNOĞLU, Nuray (2007), "Sosyal Bilimler Alanindaki Araştırmalarda Bilimsel Araştırma Süreci, İstatiksel Teknikler ve Hatalar", Ticaret ve Turizm Egitim Fakültesi Dergisi, S.1, ss.1-20.

UÇAR, Nezihe (2006), "Parametrik Olmayan (Non-Parametric) Hipotez Testleri", SPSS Uygulamalı Çok Değişkenli İstatistik Teknikleri (Ed. Şeref KALAYLI), Asil Yayınları, Ankara, 5.Baskı, ss.83-112.

VERSAN, Vakur (1986), Kamu Yönetimi Siyasi ve İdari Teşkilat, Der Yayınları, İstanbul.

YILDIRIM, Turan (2005), Türkiye’nin İdari Teşkilatı, Alkım Yayınevi, İstanbul.

YILDIRIM, Turan, YASİN, Melikşah, KAMAN, Nur, ÖZDEMIIR, Halit Eyüp, ÜSTÜN, Gül ve TEKİNSOY, Özge (2012), İdare Hukuku, On İki Levha Yayıncılık, İstanbul.

Türkiye Cumhuriyeti Anayasası (09.11.1982 tarih ve 17863 sayılı Resmi Gazete).

657 sayılı Devlet Memurları Kanunu (23.07.1965 tarih ve 12056 sayılı Resmi Gazete).

4857 sayılı İş Kanunu (10.06.2003 tarih ve 25134 sayılı Resmi Gazete). 
5174 sayılı Türkiye Odalar ve Borsalar Birliği ile Odalar ve Borsalar Kanunu (01.06.2004 tarih ve 25479 say1lı Resmi Gazete).

5590 sayılı Mülga "Ticaret Ve Sanayi Odalari", "Ticaret Odalari", "Sanayi Odalari", "Deniz Ticaret Odalari", "Ticaret Borsalari" Ve "Türkiye Ticaret, Sanayi, Deniz Ticaret Odalari Ve Ticaret Borsalari Birliği" Kanunu (15.03.1950 tarih ve 7457 sayılı Resmi Gazete).

Bakanlar Kurulu'nun 5590 sayılı kanuna dayanılarak 18.5.1983 tarih ve 83/6620 sayılı kararı ile kabul edilen Ticaret ve Sanayi Odalari, Ticaret Odalari, Sanayi Odalari, Deniz Ticaret Odalari, Ticaret Borsalari ve Türkiye Ticaret, Sanayi; Deniz Ticaret Odalari ve Ticaret Borsalari Birliği Personel Yönetmeliği (05.08.1983 tarih ve 18126 say1lı Resmi Gazete).

Bakanlar Kurulu'nun 5590 sayılı kanuna dayanılarak 21.09.1994 tarih ve 94/6101 sayılı kararı ile kabul edilen Ticaret ve Sanayi Odalari, Ticaret Odalari, Sanayi Odalari, Deniz Ticaret Odalari, Ticaret Borsalari ve Türkiye Ticaret, Sanayi; Deniz Ticaret Odalari ve Ticaret Borsalari Birliği Personel Sicil Yönetmeliği (03.11.1994 tarih ve 22100 say1lı Resmi Gazete). 